Lilianna Wdowiak, Paweł Wysokiński

Samodzielna Pracownia Edukacji Medycznej

Pomorski Uniwersytet Medyczny w Szczecinie

\title{
OWADY JAKO REMEDIA W POLSKIM LECZNICTWIE LUDOWYM DOBY ZABORÓW I II RZECZYPOSPOLITEJ
}

\author{
Insects as remedies in Polish folk medicine at the time of partitions \\ and the 2nd Polish Republic
}

Insects constitute as much as $75 \%$ of all described species of the world's fauna. In the animal kingdom they play a dominant role. To certain extent it was reflected in folk medicine using zoonotic drugs. The purpose of the work is to determine, what kinds of insects were used the time of Poland's partitions and in the 2nd Polish Republic. Insects were used most often in such diseases, as: rheumatoid arthritis, paralysis, circulatory insufficiency and resulting oedemas, malaria, erysipelas, rabies, viper bites, trachoma, jaundice, skin diseases, cuts, hysteria. Close to 20 insect families were applied in folk medicine, although not all of the species can be counted, the more so as they were not always distinguished by the people of old Polish territories - both peasants and the researchers of their culture. Most often beetles and hymenopteras were used, less often - butterflies. There was widespread belief connected with this therapy, i.e. belief in magical meaning of numbers, especially number 3 and its multiple

Słowa kluczowe: etnozoologia, etnomedycyna, lecznictwo ludowe

Keywords: ethnozoology, ethnomedicine, folk medicine

Wśród ogromnej gamy leków stosowanych w lecznictwie ludowym na ziemiach polskich, tak jak na całym świecie, największą popularność zdobyły specyfiki roślinne, a dopiero $w$ drugim rzędzie sięgano po środki pochodzące ze świata zwierzęcego. Pośród tych ostatnich niepoślednią rolę odgrywały owady. Chociaż stanowią one aż 75\% wszystkich opisanych gatunków fauny świata ${ }^{1}$, na tle innych remediów

${ }^{1}$ H. Sand ner: Owady, Warszawa 1989, s. 9. 
odzwierzęcych ich udział w ludowych medykamentach wydawał się prezentować dość skromnie. W lecznictwie służyły one do różnych celów - począwszy od „zbrzydzania" choroby, pojmowanej, jako spersonifikowane zło, któremu usiłowano różnymi metodami zohydzić pobyt w ludzkim ciele i go wypłoszyć - po wykorzystywanie ugryzień insektów do zwalczania czynników patogennych.

W niniejszej pracy podjęta została próba ustalenia, jakich konkretnie rodzin owadów i ich gatunków używano niegdyś w lecznictwie ludowym. Analiza materiałów etnograficznych pochodzących z XIX w. i pierwszej połowy XX w., zawartych głównie w pracach Oskara Kolberga, „Zbiorze Wiadomości do Antropologii Krajowej”, „Materyałach Archeologiczno - Antropologicznych i Etnograficznych”, „Ludzie” i „Wiśle” oraz niegdyś poczytnych pismach o charakterze krajoznawczym, takich jak „Kwartalnik Litewski” i „Ziemia”, czy poszukiwania w monografiach dotyczących poszczególnych regionów dawnych ziem polskich, pozwoliły przypuszczać, iż terapeuci ludowi używali w leczeniu różnych schorzeń bardzo wielu owadów żyjących w najbliższym otoczeniu, niekiedy tylko zalecając swoim pacjentom kupno gotowych preparatów w aptekach. Na przykład pospólstwo zamieszkałe na dawnych ziemiach polskich domagało się dość powszechnie od aptekarzy mitycznego „komarzego" sadła, które miało służyć do smarowania klatki piersiowej w razie wystąpienia kaszlu. Zwykle, jako „komarze sadło” w końcu XIX w. sprzedawano świński tłuszcz², a później płynną wazelinę lub lanolinę 3 .

Temat owadów został już podjęty w artykule Olgi Zadurskiej ${ }^{4}$, lecz autorka wymieniła jedynie dwa lekarstwa stosowane w lecznictwie ludowym w leczeniu róży. Napomknęła, że leczono owadami również żółtaczkę i bezsenność, tymczasem lista schorzeń, które kurowano przy pomocy owadów należy do dość pokaźnych. Jak nam się wydaje, również należy uznać za błąd utożsamianie owadów z robakami. W mowie potocznej pod pojęciem „robaki” kryły się także skorupiaki czy skąposzczety a nawet pajęczaki, więc nie można pomiędzy terminem „owady” a „robaki” postawić znaku równości.

\section{„Muszka hiszpańska” i oleice}

Pośród owadzich środków terapeutycznych, najbardziej chyba znanym, była ceniona od starożytności „hiszpańska mucha”, czyli kantaryda, silny afrodyzjak. Po bliższym przyjrzeniu się owadowi, słynna „hiszpańska mucha” okazała się nie muchówką, lecz chrząszczem: dwucentymetrowym, metalicznie lśniącym, o zielo-

\footnotetext{
${ }^{2}$ Pobratymiec [J. S. Płatkowski]: Środki lecznicze i ich nazwy aptekarskie u ludu (z powiatu myślenickiego), „Lud” t. 5: 1899 s. 164.

${ }^{3}$ S. Spittal: Lecznictwo ludowe w Załoźcach i okolicy. Materiały dotyczq̨ce sposobów leczenia, zielarstwa, wierzeń, zabobonów i znachorstwa, „Rocznik Podolski” t. 1: 1938 s. 178.

${ }^{4}$ O. Zadurs ka: „Każdy ma swego robaka”. O owadach w polskiej medycynie ludowej, „Tekstura. Rocznik Filologiczno-Kulturoznawczy" t. 1: 2013 s. 27-37.
} 
no-szmaragdowym ubarwieniu. Pryszczel lekarski, majka lekarska, zwana inaczej kantarydą (Lytta vesicatoria), należy do rodziny oleicowatych, nazywaną niekiedy rodziną maikowatych (Meloidae), żeruje najczęściej na jesionach, chociaż owad spotkać można również na klonach, topolach ${ }^{5}$, bądź lilakach pospolitych, potocznie nazywanych bzami. Chociaż chrząszcz preferuje drzewa rosnące w krajach Europy Południowej, występuje również w Polsce. Zaatakowana kantaryda wydziela poprzez gruczoły umiejscowione w okolicy stawów kolanowych płyn zawierający kantarydynę - związek toksyczny dla niektórych zwierząt. W przypadku przedawkowania powoduje on również poważne zatrucia u ludzi ${ }^{6}$.

Niewiele źródeł wskazuje na to, że i polscy chłopi zapoznali się z afrodyzjakowymi właściwościami „hiszpańskiej muchy”, chociaż skutki jej używania zapewne lepiej poznały i odczuły sfery wyższe naszego społeczeństwa. Piszący o mieszkającej w pobliżu Międzyrzecza Podlaskiego drobnej szlachcie (tzw. bojarach) oraz o ludności chłopskiej, ksiądz Adolf Pleszczyński (1841-1925) twierdził, iż używano tam kantaryd do sporządzania nalewki traktowanej jako comfortativum ${ }^{7}$. Kantarydami ludność ziem polskich posługiwała się zazwyczaj przy wytwarzaniu wezykatorii, okładów mających wywołać miejscowy stan zapalny skóry. Już w latach 60. XIX stulecia Walery Wielogłowski (1805-1865), autor moralizatorskiego dziełka „Medycyna wiejska" grzmiał:

To wezykatorye!! któż był taki głupi poradzić wam to lekarstwo?”, ale jeszcze długo potem nie tylko znachorzy, lecz i autorytety lekarskie, sięgały po wezykatorie, przede wszystkim w leczeniu histerii oraz dolegliwości bólowych.

Do leczenia zapaleń i gorączek

...jako okładu używają majek zielonych (Lytta vesicatoria), które potłuczone lub starte przykładają na płatkach płóciennych bądź do karku, bądź do miejsc bolących ${ }^{9}$

- pisał o podolskich chłopach lekarz, Stanisław Spittal (1891-1964). Nieopodal Witebska na kark i za uszy kładziono „muszki”, czyli „francuskie plajstry”, którymi kurowano bóle głowy ${ }^{10}$. Bardziej wytworne „wizykatorye” polecała wcześniej Karolina z Potockich Nakwaska (1798-1875) mieszkańcom dworów - „...osobom skłonnym do humorów, zapalenia ócz, wyrzutów na twarzy i krost". Nakazywano

${ }^{5}$ H. Sandner: s. 57.

${ }^{6}$ D. J. Karras, S. E. Farrell, R. A. Harrigan, F. M. Henretig, L. Gealt: Poisoning from "Spanish fly" (cantharidin), „The American Journal of Emergency Medicine” t. 14: $1996 \mathrm{nr} 5$ s. 478-483.

${ }^{7}$ A. Ples zczyńs ki: Bojarzy Międzyrzeccy. Studjum etnograficzne, Warszawa 1892, s. 120.

${ }^{8}$ W. Wielogłowski: Medycyna wiejska. Obrazek z obyczajów ludu wiejskiego, Kraków 1863, s. 55.

${ }^{9}$ S. Spittal: s. 179.

${ }^{10}$ F. We reńko: Przyczynek do lecznictwa ludowego, „Materyały Antropologiczno-Archeologiczne i Etnograficzne" t. 1: 1896 cz. 2 s. 140. 
przylepiać na ręku plaster o wielkości dłoni, na którym umieszczano proszek kantarydowy, maść różaną i olejek lawendowy.

Jeśli wizykatorya zbyt rozjątrzona i zapalenie wielkie, trzeba przykładać, dla uśmierzenia bólu, masła zupełnie świeżego, smarując niem liście ślazowe ${ }^{11}$ - zapewniała autorka.

$\mathrm{Na}$ Kaszubach „muszki kantarydowe” używane były do leczenia paraliżu ${ }^{12}$. Natomiast w niegdyś sapieżyńskiej Lepeli nieopodal Witebska psom, które ukąsiło wściekłe zwierzę, serwowano „...po kilka sztuk muszek hiszpańskich w chlebie zagniecionych"13 i jak twierdził Julian Talko-Hryncewicz (1850-1936), podobnie postępowano wobec ludzi i zwierząt podejrzanych o wodowstręt na terenach północnych Podlasia ${ }^{14}$.Podawał również, iż na Ukrainie jednym ze sposobów przygotowywania lekarstwa na wściekliznę było sporządzenie garnka odwaru z „winników”, do którego wrzucano garść majek. „Winniki” okazały się rośliną z rodziny kapustowatych - stulichą psią (Descurainia sophia) ${ }^{15}$.

Leczenie wścieklizny za pomocą chrząszczy (rząd Coleoptera) można było odnotować prawie na całym terenie dawnej Polski, lecz rzadko sięgano w takich przypadkach po kantarydy, posługując się dość powszechnie ich bliskimi kuzynkami z rodziny Meloidae: oleicą krówką (Meloe proscarabaeus) czy oleicą fioletową (Meloe violaceus) oraz innymi, bliżej nieokreślonymi oleicami. Przedstawicieli tej rodziny występuje w dzisiejszej Polsce 13 gatunków. Obecnie wszystkie te chrząszcze można napotkać w ich starych siedliskach niezwykle rzadko, chociaż pszczelarze ubolewają, iż pasieki narażane są wręcz na inwazję larw oleic. Jak się wydaje, oleice dawniej występowały w większej obfitości. Trudno sprecyzować, których konkretnie gatunków oleic używano poza oleicą krówką czy myloną z nią oleicą fioletową, bowiem obie funkcjonowały pod różnymi odmianami określenia „majka” (np.: maika, maik, majik, majak, majek, majouk, majówka), co zapewne było związane z ich masowym pojawieniem się w maju.

W roku 1830 w czasopiśmie „Piast”, zawierającym zazwyczaj tłumaczone z języków obcych materiały, redakcja zamieściła artykuł nieznanego z pełnego imienia W. J. Meisnera o leczeniu wścieklizny, który jako składnik niezawodnego remedium na wodowstręt zalecał „robaki majowe”. „Maiowy robak iest gadzina, która od Linneusza w Klassie Coleopterorum się kładzie, i Meloe się nazywa. Źle go nazywać maiowym

${ }^{11}$ K. Nakwaska: Dwór wiejski. Dzieło poświęcone gospodyniom polskim. Przydatne i osobom w mieście mieszkającym, t. 3, Lipsk 1860, s. 264.

${ }^{12}$ J. Torliński: Przesądy i zwyczaje lecznicze kaszubskich rybaków nadmorskich, „Archiwum Historii i Filozofii Medycyny i Historii Nauk Przyrodniczych” t. 17: 1938 z. 1-2 s. 131.

${ }^{13}$ F. Wereńko: s. 189.

${ }^{14}$ J. Talko-H ryncewicz: Zarysy lecznictwa ludowego na Rusi Południowej, Kraków 1893, s. 197.

${ }^{15}$ Tamże: s. 253. 
chrząszczem, i z pospolitym chrząszczem go pomieszać..." ${ }^{\text {- }}$ - pisał autor powołując się na dane pochodzące jeszcze z końca XVIII w. Meissner wyróżniał dwa rodzaje „robaków majowych" - czarną oleicę krówkę i inny jeszcze gatunek oleicy, o żółtawym ubarwieniu. „Te robaczki maiowe naypryncypalnieysze są ingrediens tego sławnego arcanum...” - podkreślał. Aby przygotować słynne arcanum, należało za pomocą drewienek zebrać około 170-200 oleic i „...tedy im żyiącym ieszcze, iednak nie dotykaiąc się ich, głowę nożyczkami nad szklanką, w którey czysty iest miód, uciąć, odrzucić, ciało zaś w miód kłaść trzeba” ${ }^{17}$. Autor zalecał, aby zawarta w robakach „materya” (kantarydyna ${ }^{18}$ ) koniecznie trafiła do miodu, ,....ponieważ ta do uleczania należy”. Zakonserwowane w miodzie oleice przechowywać można było przez kilka lat, o ile naczynie było szczelnie zakorkowane.

Jak się wydaje, niezależnie od tych prasowych doniesień, ludność wiejska stosowała oleice w zapobieganiu wściekliźnie chyba od bardzo dawna, o czym świadczą zupełnie inne metody konserwowania owadów, albo wyciskanie bezpośrednio na ranę cieczy zawartej w majkach. W Galicji czyniły tak dzieci w przypadku jakichkolwiek skaleczeń ${ }^{19}$, niekoniecznie zadanych przez zwierzę podejrzane o wściekliznę. Kantarydynę stosowano również w terapii owrzodzeń. „Dobrze jest pomazać wrzód sokiem z majówki"20 - pisał Marian Udziela (1863-1921) o lecznictwie ludowym w Małopolsce. Na Białorusi kurowano „majoukiem utopionym w miodzie” ugryzienia żmii ${ }^{21}$, co miało spowodować zmniejszenie obrzęku. W okolicach Kalisza twierdzono, iż

...na ukąszenie psa wściekłego należy nazbierać robaków, maikami zwanych, odciąw-

szy niepotrzebne łapki, namoczyć resztę w okowicie i tym trzy razy dziennie smarować chorego ${ }^{22}$.

Na Kujawach zastępowano alkohol oliwą:

Owad, zwany majkiem, a który tylko w maju złowiony być powinien, wkłada się do słoika z oliwą. Pokąsany przez psa wściekłego zjada tak zakonserwowanego majka z chlebem, a jeżeli później uczuwa boleści, jest to dowód, że mu groziło niebezpieczeństwo, które jednak dzięki majkowi, przeminęło ${ }^{23}$.

${ }^{16}$ W. J. Meis ner: Lekarstwo na wściekliznę (wodowstręt), „Piast czyli Pamiętnik Technologiczny. Obeymuiący przepisy dla gospodarstwa domowego i wieyskiego, ogrodnictwa, sztuk pięknych, rękodzielń i rzemiosł; niemniey lekarstwa domowe, pospolite i zwierzęce" t. 19: 1830 s. 127.

17 Tamże, s. 129.

${ }^{18}$ Pierre Jean Robiquet (1780-1840), francuski chemik opisał kantarydynę w $1810 \mathrm{r}$.

${ }^{19}$ W. Kosińs ki: Materyały etnograficzne zebrane w różnych okolicach Galicyi zachodniej, „Materyały Antropologiczno-Archeologiczne i Etnograficzne” t. 7: 1904 cz. 2 s. 34.

${ }^{20}$ M. Udzi ela: Medycyna i przesądy lecznicze ludu polskiego. Przyczynek do etnografii polskiej, Warszawa 1891, s. 233.

${ }^{21}$ F. Wereńko: dz. cyt. s. 202.

${ }^{22}$ M. Parcz ews ka: Lecznictwo ludowe w okolicach Kalisza, „Wisła. Miesięcznik Geograficzno-Etnograficzny" t. 10: 1896 z. 2 s. 344.

${ }^{23}$ H. Sarnow ska: Niektóre sposoby leczenia na Kujawach, „Wisła. Miesięcznik Geograficzno-Etnograficzny" t. 10: 1896 z. 2 s. 345. 
Ludowy sposób leczenia wścieklizny na Kujawach zupełnie nie trafiał do przekonania Oskarowi Kolbergowi (1814-1890), który napisał: „Na wściekliznę przesąd daje zwykle wypić majika (owad) w oliwie, co owszem jak najgorsze sprowadzać za sobą zwykł skutki"24.

Również Ludwik Jucewicz (1810-1846) podawał, iż na Litwie osobom pokąsanym przez wściekłe zwierzęta zalecano zjeść sproszkowaną majówkę bądź kan$\operatorname{tarydę~}^{25}$. Na Żmudzi, aby ratować pogryzionych przez zwierzęta chorujące na wodowstręt, przyrządzano „...proszek z narządu usznego u prosiąt z wysuszonymi majkami"26.

Na Mazowszu, w okolicach Radzymina podawano pokąsanym usmażone owa$\mathrm{dy}^{27}$, natomiast na Lubelszczyźnie w pobliżu Hrubieszowa przygotowywano z oleic „ozdrowieńczą” zupę. Ukrywająca się pod inicjałami Z. St., nieznana bliżej Zofia Staniszewska, autorka pracy „Znad Buga”, pisząc o rodzaju barszczu, czy może żurze (wspominała o sfermentowanym chlebie), dostrzegła w cieczy szczątki maika:

...gdyż cząsteczki jego bardzo wyraźnie rozróżnić można było - skrzydełka, czasem główka źle roztarta; w jaki jednakże sposób [znachor] wszystko razem przyrządzał, niepodobna się było dowiedzieć... ${ }^{28}$.

Nawiasem mówiąc, zupę z chrząszczy przygotowywano jeszcze do połowy XX wieku na terenie Hesji w Niemczech i we wschodnich rejonach Francji, jednakże używano chrabąszczy majowych. W połowie XIX stulecia lekarz z Fuldy, Johann Joseph Schneider polecał przygotowywanie zupy z chrabąszczy na wzmocnienie, zwłaszcza podczas rekonwalescencji ${ }^{29}$.

\section{Chrabąszcze}

W lecznictwie ludowym na ziemiach polskich również używano chrabąszczy (należą do rodziny poświętnikowatych), jednakże dzisiaj trudno z całą pewnością stwierdzić, jakie to były gatunki. Chrabąszcz majowy (Melolontha melolontha), chrabąszcz kasztanowy (Melolontha hippocastani) oraz guniak czerwczyk (Amphimallon solstitiale) są bardzo do siebie podobne i zapewne wszystkie te owady potocznie nazywano chrabąszczami. Na Podolu w leczeniu reumatyzmu stosowano naciera-

${ }^{24}$ O. Kolberg: Kujawy cz. 1, [w:] tenże: Dzieła wszystkie, t. 3, Warszawa 1962, s. 95.

${ }^{25}$ L. A. Ju ce wi cz: Litwa pod względem starożytnych zabytków, obyczajów i zwyczajów skreślona przez Ludwika z Poklewia, Wilno 1846, s. 341.

${ }^{26}$ J. Talko-Hryncewicz, dz. cyt s. 446.

27 W. H.: Poszukiwania, „Wisła. Miesięcznik Geograficzno-Etnograficzny” t. 6: 1892 z. 1 s. 223 .

${ }^{28}$ Z. St.: Znad Buga, „Lud” t. 3: 1897 s. 25-26.

${ }^{29}$ J. J. Schn eid er: Maikäfersuppen, ein vortreffliches und kräftiges Nahrungsmittel, „Magazin für die Staatsarzneikunde" t. 3: 1844 nr 3 s. 403-405. 
nia za pomocą nalewki wódczanej na chrabąszczach ${ }^{30}$, na terenie Białorusi moczono pędraki chrabąszcza (biełyja rabaki) w wódce i dodawano ją do owsa, aby zlikwidować u koni i bydła hrude (grudę - grzybicę nóg) ${ }^{31}$. „Nałapać chrabąszczów do flaszki, nalać okowitą i zakopać na dziewięć dni do ziemi, aby słońca nie widziały; potem okowitę tę zlać do innej flaszki i używać do nacierania na różne boleści" ${ }^{32}$ - zalecano w Małopolsce. Na Ukrainie z chrabąszczy przygotowywano wódczaną nalewkę, którą stosowano zarówno zewnętrznie, jak i wewnętrznie w zwalczaniu reumatyzmu ${ }^{33}$. Na Białorusi schorzenia układu moczowo-płciowego u krów, których objawem był „mocz krwawy” kurowano podając bydłu żywe żuki gnojowe (Geotrupes stercorarius) z wodą lub z chlebem ${ }^{34}$. Czornyje żuki służyły również ludziom w tym rejonie jako remedium na zimnicę ${ }^{35}$. Żuki gnojowe zaliczano niegdyś do żukowatych, a dzisiaj do gnojarzowatych.

\section{„Robaczki świętojańskie”}

Do rzędu chrząszczy (Coleoptera) należy również rodzina świetlikowatych (Lampyridae). Na terenie Polski występują trzy gatunki „robaczków świętojańskich": świetlik świętojański (Lampyris noctiluca), iskrzyk (Phausis splendidula) oraz świeciuch (Phosphaenus hemipterus). „W niektórych okolicach lud utrzymuje, że świecące wieczorem robaczki świętojańskie, to dusze proszące o modlitwę" ${ }^{36}$ pisał o wierzeniach małopolskich chłopów Franciszek Gawełek (1884-1919) . Ludowi terapeuci wykorzystywali święcące w mroku (a więc - niecodzienne, zupełnie odmienne, wyjątkowe) owady do leczenia róży (erysipelas) - także uważaną za „specjalną” chorobę. „Trzeba w maju znaleźć 3 razy 9 robaczków świętojańskich, rozetrzeć je na dłoni i zostawić tak, aby zaschły. Taką dłonią naciera się dotknięte różą miejsce trzy razy"37 - napisał o praktykach litewskich Wandalin Szukiewicz (1852-1919). W podobny sposób leczono różę w okolicach Witebska:

Około św. Jana nałapać robaczków świętojańskich i natarłszy nimi swe ręce, nie myć ich w ciągu dni trzech. Od potarcia miejsca chorego rękoma przez osobę, która postąpiła jak wyżej, róża ustępuje niechybnie ${ }^{38}$ - podawał Franciszek Wereńko (?-1912).

\footnotetext{
${ }^{30}$ S. Spittal: s. 216.

${ }^{31}$ F. Wereńko: s. 222.

${ }^{32}$ S. Ud zi ela: Materyjały etnograficzne z miasta Ropczyc i okolicy, Kraków 1886, s. 25.

${ }^{33} \mathrm{~J}$. Talko-Hryncewicz: s. 319.

${ }^{34}$ F. Wereńko: s. 224.

35 Tamże, s. 167-168.

${ }^{36}$ F. Gawełek: Przesądy, zabobony, środki lecznicze i wiara ludu w Radłowie w pow. Brzeskim, „Materyały Antropologiczno-Archeologiczne i Etnograficzne” t. 11: 1910 cz. 3 s.76.

${ }^{37}$ W. Szu ki ewi cz: Wierzenia i praktyki ludowe (zabobony, przesądy, wróżba i t. d.), zebrane w gubernji Wileńskiej (Dokończenie), „Wisła” t.17: 1903 z. 4 s. 441.

${ }^{38}$ F. Wereńko: s. 185.
} 
Ręce natarte [...] robaczkiem świętojańskim i przez całą dobę potem nie myte, mają przez cały rok własność leczenia róży przez trzykrotne dotknięcie chorego miejsca"39 - wierzono na Wołyniu. W innych rejonach Ukrainy terapia róży za pomocą robaczków należała już do bardziej skomplikowanych. Należało nałowić robaczków świętojańskich dokładnie w noc Iwana Kupały i podobnie, jak gdzie indziej, rozetrzeć je w dłoniach. Jeśli róża pojawiła się zimą, przez tydzień pocierano dłońmi chore miejsce, zaś latem wystarczyło dotknąć je dwa razy ${ }^{40}$.

\section{Biedronki}

Szczególną sympatią mieszkańcy dawnych ziem polskich darzyli biedronki owady zaliczane również do rzędu chrząszczy. W dzisiejszej Polsce żyje 76 gatunków należących do rodziny biedronkowatych (Coccinellidae). Spośród nich najbardziej znana jest biedronka siedmiokropka (Coccinella septempunctata). Chyba żadnemu innemu bytującemu na dawnych ziemiach polskich owadowi nie nadano tyle nazw co biedronce. Bronisław Gustawicz (1852-1916) pisał: „...w Brzeżańskiém zowią [ją] kukułką lub zazulą, w Bobreckiém zazulką i bożą krówką, a w Szołomyi sedmówką"41. Na Ukrainie określano ją także mianem konopelki. W miasteczku Radłów niedaleko Tarnowa nazywano biedronkę „patronką”, „panienką”, „owieczką Pana Jezusa"42. Trudno przytoczyć wszystkie ludowe nazwy nadawane biedronkom. Na przykład Jan Świętek (1859-1926), który prowadził badania folklorystyczne w Małopolsce, odnotował, iż ludność zamieszkująca nad Rabą nazywała biedronkę „katką-matką" i uważała ją za wysłanniczkę niebios.

Gdy usiędzie na ręku dziecka, podnosi ono tę rękę w górę i błagalnym głosem zwraca się do biedronki: Katka-matka, idź do nieba,

I przynieś mi kromkę chleba;

A nie daj go carownicy,

Co tam siedzi na ulicy.

Na to wezwanie zbiera się katka-matka na skrzydełka, a uniósłszy się w górę, ma za chwilę przynieść z nieba za pożądany chleb gęsty sok żółtawy ${ }^{43}$.

Zaniepokojona biedronka wydziela hemolimfę, podobnie inne bezkręgowce mające otwarty układ krwionośny.

Biedronki powszechnie służyły do najróżniejszych wróżb, nie tylko na dawnych ziemiach polskich, ale i w całej Europie.

${ }^{39}$ I. Ko p ernicki: Przyczynek do etnografii ludu ruskiego ma Wołyniu z materyjałów zebranych przez p. Zofiję Rokossowska we wsi Jurkowszczyźnie w pow. Zwiahelskim, „Zbiór Wiadomości do Antropologii Krajowej" t. 11: 1887 cz. 3 s. 215.

${ }^{40} \mathrm{~J}$. Talko-Hryncewicz: dz. cyt. s. 303-304.

${ }^{41}$ B. Gustawicz: Podania, przesqady, gadki i nazwy ludowe $w$ dziedzinie przyrody. Część pierwsza. Zwierzęta, „Zbiór Wiadomości do Antropologii Krajowej” t. 5: 1881 cz. 3 s. 182.

${ }^{42}$ F. Gawełek: s. 62.

${ }^{43}$ J. Świętek: Lud nadrabski od Gdowa po Bochnię, Kraków 1893, s. 593. 
Bożej krówce, czyli biedronce stawia się różne pytania i wyciąga wróżby z jej ruchów; u nas także chłopcy i dziewczęta, kładąc ją na ręce, pytają w następujący sposób: «Biedronka, biedronka, gdzie moja żonka», albo: «Biedronek, biedronek, gdzie mój małżonek» i z lotu owadu wróżą, z której strony przybędzie do nich kawaler, lub gdzie przebywa panna im przeznaczona" ${ }^{44}$.

Seweryn Udziela (1857-1937) pisał:

Biedronka nazywa się także krówką. Dzieci biorą ją na rękę i mówią: Krówko, borówko, gdzie twoje wesele? W Krakowie, we Lwowie, «tańcują panowie». Wtedy krówka się ucieszy i odleci. Jeżeli jej zaś dzieci powiedzą w końcu: «tańcują dziadowie», to się zasmuci i nie odlatuje $\mathrm{e}^{45}$.

Zapewne biedronkę traktowano również na Litwie jako wysłanniczkę niebios, bowiem Ludwik Jucewicz napisał:

Lud litewski dziwne i nadprzyrodzone własności bożej-krówce przypisuje. Kobiety ususzony ten owad noszą w woreczkach na szyi, jako amulet ochraniający od czarów; przyłożony do twarzy, ma uśmierzać ból zębów; chowany w domu, broni od pożaru, it. d. i t. $\mathrm{d}^{46}$.

Dalej zauważał:

Nie tylko lekarstwo sympatyczne, lecz i sam rozum lud bożej-krówce przyznaje, za dowód przytaczając, iż złowiona na polu i położona na ręku, za wymówieniem słów: Petreli palek! palek! palek! Boża-krówko odleć! odleć! odleć!; natychmiast odlatuje ${ }^{47}$.

Pomimo, iż biedronki traktowano w sposób wyjątkowy, masowo traciły życie, służąc jako składniki lekarstw. Kobietom, które przestawały miesiączkować (jak twierdził autor doniesienia - z powodu przeziębienia) zalecano w Tarczynie (Mazowsze) i w Będzinie (Śląsk) picie nalewki spirytusowej na biedronkach ${ }^{48}$. Podobną nalewkę podawano w okolicach Witebska w przypadłościach sercowych. Przyrządzano ją z biedronki siedmiokropki (bożaja karouka). Czasami mieszano różne gatunki biedronek i ucierano je z wodą i cukrem. Biedronki uchodziły za środek skuteczny w zapaściach, lecz „nader energiczny”, toteż stosowano je z dużą ostrożnością - pijąc po pół kieliszka nalewki raz dziennie. Już po dwóch dniach spożywania tych biedronkowych remediów podobno było wiadomym, czy chory umrze, czy będzie nadal żyć ${ }^{49}$.

${ }^{44}$ W. Marrené: Rzeczy ludowe włoskie, „Wisła. Miesięcznik Geograficzno-Etnograficzny” t. 3: 1889 z. 4 s. 826.

${ }^{45}$ S. Udziela: s. 23.

${ }^{46}$ L. Jucewicz: s. 129.

${ }^{47}$ Tamże.

${ }^{48}$ A. Wiśniewski: Lecznictwo ludowe, „Wisła. Miesięcznik Geograficzno-Etnograficzny” t. 5: 1891 z. 3 s. 643.

${ }^{49}$ F. Wereńko: s. 154. 


\section{Inne chrząszcze}

Jako zasypek do jątrzących się ran używano trocin, które wyprodukowały chrząszcze. Rzadko używanymi w lecznictwie ludowym owadami były kołatki (Anobiidae) zwane powszechnie (acz błędnie) kornikami. Wykorzystywano sypiące się z mebli próchno do leczenia ran i otarć naskórka. Podobnie działo się z próchnem wytwarzanym w lasach i sadach przez prawdziwe korniki (Scolytinae) z rodziny ryjkowcowatych. „Wyprzenia ciała posypują bądź tak zwaną cérwotocyną, t. j. próchnem z drzewa, utoczonem przez robaki"50 - pisał Jan Świętek o zachowaniach ludności Małopolski.

Niektóre chrząszcze budziły strach. W Galicji należał do nich metalicznie lśniący biegacz wręgaty (Carabus cancellatus) należący do rodziny biegaczowatych (Carabidae), nazywany „szczypicą”, a w okolicach Lwowa „kliszczem”. „Szczypicy” nie wolno było zabić w domu, trzeba ją było wynieść albo spalićs1. „Szczypawką”, „szczypawicą”, „korcem”, „zausznikiem” nazywano także inny gatunek owadów należących już nie do chrząszczy, lecz do skorkowatych. Skorek pospolity (Forficula auricularia) również powodował zaniepokojenie i lęk mieszkańców wsi i miasteczek.

\section{Mrówki}

Do innego już rzędu - błonkówek (błonkoskrzydłe - Hymenoptera) należą mrówki czy pszczoły. W Polce żyje ponad 100 gatunków mrówek, z których tylko część znajduje się pod ochroną - np. mrówka łąkowa (czarniawka) - Formica pratensi, mrówka pniakowa - Formica truncorum, mrówka północna - Formica aquilonia, czy smętnica - Formica lugubris ${ }^{52}$. Dawni mieszkańcy ziem polskich, podobnie jak współcześni, nie odróżniali poszczególnych gatunków mrówek, jednakże czynili wyjątek dla mrówki rudnicy. „Duże mrówki z rodzaju rudnic (Formica rufa) zowią murachami, muraszkami [...] lub kowalami..." ${ }^{53}$ - podawał przyrodnik i folklorysta Bronisław Gustawicz. Nazw „murachy” i „muraszki” miano używać na ziemi lwowskiej, a nazwę „kowali” nadali rudnicom Krakowianie. Lecz już na Podhalu nazywano mrówkę „mrowiecką”, duże, czarne mrówki lub małe czerwone zwano „żydowskimi mrowcami” ${ }^{54}$. Na Podlasiu, podobnie jak we Lwowskim używano terminu „muraszka”. Wysyłani przez znachorów do aptek podlascy chłopi prosili o spirytus muraszkowy, muraszkowe krople, muraszkową wodę, a nawet spirytus „morowy” 55 .

\footnotetext{
${ }^{50} \mathrm{~J}$. Świętek: Lud nadrabski... s. 607.

${ }^{51}$ B. Gustawicz: s. 168.

${ }^{52}$ W. Czechowski, A. Radchenko, W. Czechowska, K. Vepsäläinen: The ants of Poland with reference to the myrmecofauna of Europe, Warszawa 2012.

${ }^{53}$ B. Gustawicz: s. 246.

${ }^{54}$ J. Kantor: Czarny Dunajec, „Materyały Antropologiczno - Archeologiczne i Etnograficzne" t. 9: 1904 cz. 2 s. 207.

${ }^{55}$ A. Pleszczyński: s. 143.
} 
Spiritus formicarum, spirytus mrówczany, dobry jest do smarowania członków słabych usypiających i bolesnych. W domu przyspasabia się napełniając butel mrowiskiem i nalewając alkoholem lub tęgą wódką ${ }^{56}$

- zalecał poznański lekarz Teodor Teofil Matecki (1810-1886) w swoim poradniku w 1860 r. Używając określenia „alkohol” - miał prawdopodobnie na myśli spirytus.

Po spirytus mrówczany sięgały różne warstwy społeczne, a stosowano go zarówno w lecznictwie oficjalnym, jak i ludowym przy leczeniu wielu schorzeń. Napełniano „butel” mrowiskiem we wszystkich rejonach dawnej Polski, nalewka na mrówkach uznawana była bowiem za znakomity środek na „darcie w kościach” czyli bóle spowodowane przez gościec stawowy, jak również przypisywano jej cudowne działanie w przypadku paraliżu. Czasami stosowano mrówki zalane wrzątkiem. Na Lubelszczyźnie „Paraliż zamawiają, a potym przykładają na członek sparaliżowany mrówki parzone"57 - podawała Janina Bogdanowiczówna (1874-1907?), opisując zachowania ludności zamieszkałej w okolicach Chełmu. Lecz w rejonie Konina zalecano takie właśnie mrówki w „macicznych chorobach” do nasiadówek - „...wygotowane mrówki, wlewają w jakie naczynie drewniane i siadają na naczyniu, aby para wewnątrz przenikała" ${ }^{\prime 5}$.

Różnorakie przepisy na używanie mrówek do leczenia reumatyzmu na północnych Kresach podawał Franciszek Wereńko. Według jednego z nich, należało sporządzić wywar z mrówek i wlać go do kąpieli59 ${ }^{5}$. Mrówki musiały pochodzić z dziewięciu mrowisk, a do przygotowania wywaru używano także bliżej nieokreślonych ziół, ale koniecznie zebranych na dziewięciu miedzach ${ }^{60}$. Ze słonych kąpieli z mrówczanym odwarem korzystali chorzy na paralusz, by przywrócić siłę sparaliżowanym członkom $^{61}$. Kąpiele z dodatkiem mrówek pochodzących z mrowisk znajdujących się pod brzozą stosowano na Podlasiu w czasie połogu, natomiast mrówki pochodzące z mrowiska usytuowanego pod grabem miały być skuteczne w kąpielach leczących zastarzałe schorzenia ${ }^{62}$. Mrówek „brzozowych” i „grabowych” używano w zwalczaniu puchliny ${ }^{63}$ - „zwyczajną” udawało się zlikwidować, ale „wodną” - gdy w ciele pozostawał ślad po wciśniętym palcu - już nie. Nacierania mrówczanym spirytusem

${ }^{56}$ T. T. Matecki: Apteczka domowa, Poznań 1860, s. 45.

${ }^{57} \mathrm{~J}$. Bogd an owiczów na: Kilka notatek z medycyny ludowej, ze wsi Nadrybie w pow. Chetmskim, „Wisła. Miesięcznik Geograficzno-Etnograficzny” t. 10: 1896 z. 2 s. 347.

${ }^{58}$ A. Milewska: Medycyna ludowa, „Wisła. Miesięcznik Geograficzno-Etnograficzny” t. 5: 1891 z. 2 s. 423.

${ }^{59}$ F. Wereńko: s. 200.

${ }^{60}$ J. Świętek: Liczby Trzy i Dziewięć w mitach, wyobrażeniach, mistycznych praktykach i w zwyczajach ludowych, „Lud” t. 11: 1905 s. 385.

${ }^{61}$ F. Wereńko: s. 142.

${ }^{62}$ A. Pleszczyński: s. 111-115.

${ }^{63}$ Tamże: s. 128. 


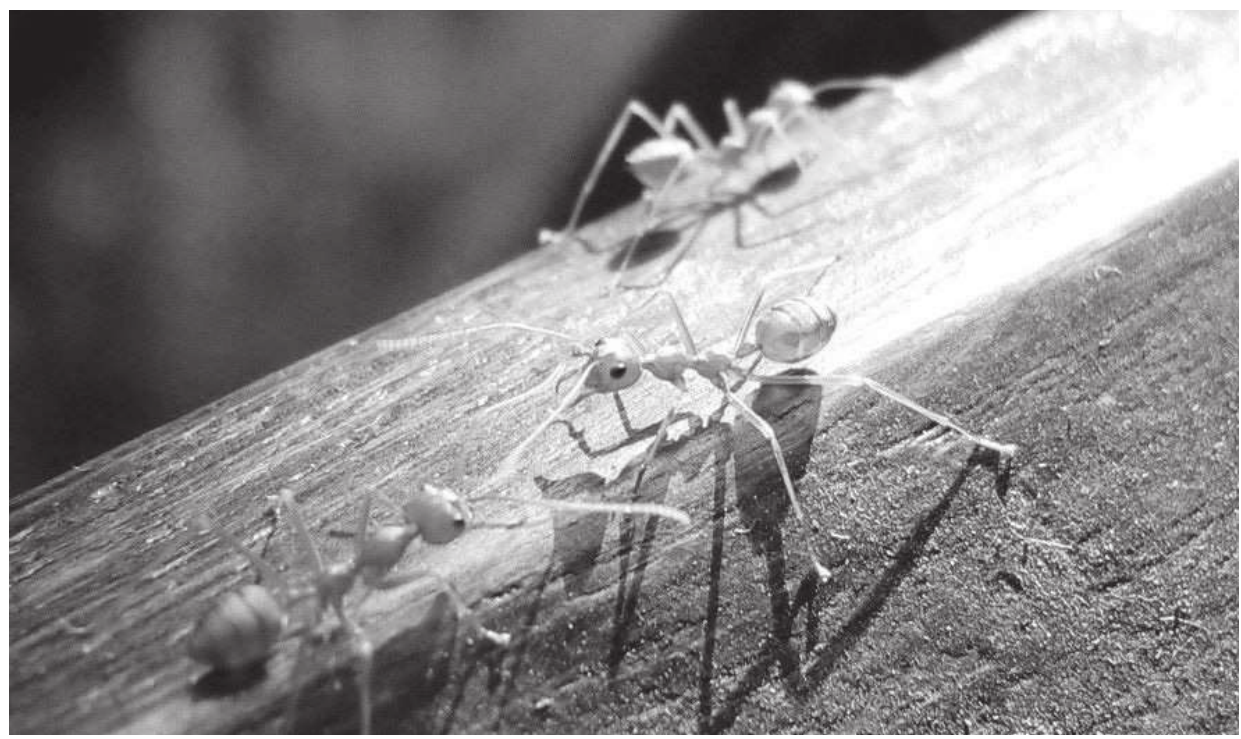

Il. 1. Robotnice mrówek - fot. L. Wdowiak

stosowano w zwalczaniu obrzęków w Małopolsce ${ }^{64}$. Kąpiel z dodatkiem mrówek pochodzących z mrowiska spod brzozy miała wzmacniać słabowite (tzw. „suchotnicze") małe dzieci w okolicach Opatowa ${ }^{65}$.

Okłady z mrówek stosowano podczas gorączki połogowej na Polesiu.

Gdy się zdarzy, że po połogu nie dość prędko następuje oczyszczenie, przez co wzmaga się gorączka i napadają boleści, przygotowują dla chorej energiczne, ale czasem skuteczne lekarstwo: mrowisko razem z mrówkami zagotowują w wodzie i potem, wyrzuciwszy na płachtę, przykładają do żołądka. Znam pewną młodą kobietę, która po takim leczeniu prędko wyzdrowiała, przedtem zaś zdawała się być bliską zgonu"66 - pisała Emma Jeleńska (1864-1919), do której rodziny należał majątek Komarowicze.

Sposobem leczenia znacznie częściej polecanym niż kąpiele czy okłady były nacierania. W powszechnym mniemaniu znakomitym środkiem na „rumatys” (,rumatyz”), zwany również „artrytusem” była specjalnie sporządzana mikstura z mrówek.

Do butelki nalewa się cokolwiek miodu i zakopuje w mrowisku; na drugi dzień wyjmuje się butelkę, napełnioną już mrówkami, szczelnie korkuje, zarabia się ciasto i piecze przez parę godzin w mocno wypalonym piecu. Otrzymany płyn, jako wcieranie, bardzo jest skuteczny przeciw wszelkim bólom reumatycznym ${ }^{67}-$ podawał Franciszek Wereńko.

${ }^{64}$ J. Świętek: Lud nadrabski... s. 623.

${ }^{65}$ S. Jastrz ębowski: Mikułowice, pow. Opatowski, gub. Radomska. Sposoby leczenia suchot u małych dzieci, „Wisła. Miesięcznik Geograficzno-Etnograficzny” t. 7: 1893 s. 745.

${ }^{66}$ E. J el eń s ka: Wieś Komarowicze w powiecie mozyrskim. Dokończenie „,Wisła. Miesięcznik Geograficzno-Etnograficzny" t. 5: 1891 z. 3 s. 507.

${ }^{67}$ F. Wereńko: s. 200-201. 
W okolicach Berdyczowa do nacierań chorych stawów używano kwasu mrówczanego, który mieszano z owczym tłuszczem ${ }^{68}$. Na Litwie postępowano bardzo podobnie, z tym wyjątkiem, iż do butelki przed włożeniem jej do ciasta i pieca wlewano ocet bądź oliwę ${ }^{69}$. Na Kresach w leczeniu reumatyzmu stosowano również poczwarki mrówek, które zalewano tęgim alkoholem, a po odstaniu nalewkę wcierano w obolałe stawy ${ }^{70}$. W podobny sposób jak na Polesiu i Litwie pozyskiwano mrówki w Małopolsce - wkładając do mrowiska naczynie z miodem. Mrówki wypełniały obficie butelkę, a wtedy zalewano je na 9 dni spirytusem, który później cedzono ${ }^{71}$. Na ziemi dobrzyńskiej również zalecano spirytus mrówczany w leczeniu „suchego bólu”, jak nazywano gościec stawowy ${ }^{72}$, podobnie postępowano w okolicach Kalisza ${ }^{73}$, czy Konina. „Nalewa się okowitę na mrówki żywe,[...] zakopuje się flaszki w mierzwę na dwa tygodnie"74 - podawała Aniela Milewska (1841-1896).

Mieszkańcy Podola również cenili mrówki jako lek na „rumatys”. W lesie wyszukiwano siedlisko mrówek, najlepiej „kowali” (Formica rufa) i chory wchodził na nie. Jak się należało spodziewać, rozwścieczone mrówki kąsały agresora. Mniej odważni chłopi decydowali się na włożenie do mrowiska odzieży.

Czasami z obawy przed mrówkami, zamiast włazić w mrowisko, wkładają do niego swoją koszulę i płócienne spodnie, a po pewnym czasie wytrzepawszy je z mrówek ubierają i noszą przepojone kwasem mrówkowym. Środek ten jednakże jest rzadziej używany, gdyż nie każdy odważy się pozostawić swoją bieliznę w mrowisku z obawy przed kradzieżą"75 - zauważał Stanisław Spittal (1891-1964).

Jak wynika z tych spostrzeżeń, ostrożni i oszczędni mieszkańcy Podola woleli wejść do mrowiska i dać się pokąsać, niż zaufać współbraciom i pozostawić w mrowisku odzież. Białorusini wkładali ręce do mrowiska i trzymali je tam przez kilka minut, aby mrówki pokąsały mocno skórę dłoni. W ten sposób usiłowano pozbyć się brodawek $^{76}$. Natomiast Izydor Kopernicki (1825-1891) podał informację, że mieszkańcy Wołynia „w mrowiskach szukają jakiegoś tłuszczu, którym posmarowane włosy rosną pięknie"77. Korzystali z mrówek również mieszkańcy Kaszub. W przypadku bólu uszu aplikowali maść sporządzoną ze zgniecionych mrówczych jaj, a gdy

\footnotetext{
${ }^{68} \mathrm{~J}$. Talko-Hryncewicz: s. 319.

${ }^{69}$ W. Szukiewicz: s. 440-441.

${ }^{70}$ F. Wereńko: s. 201.

${ }^{71}$ F. Gawełek: s. 74.

${ }^{72}$ A. Petrow: Lud ziemi Dobrzyńskiej, jego charakter, mowa, zwyczaje, obrzędy, pieśni, przysłowia, zagadki i t. p., „Zbiór Wiadomości do Antropologii Krajowej” t. 2: 1878 cz. 3 s. 139.

${ }^{73}$ M. Parczewska: s. 342.

${ }^{74}$ A. Milewska: s. 421.

${ }^{75}$ S. Spittal: s. 216.

${ }^{76}$ F. Wereńko: s. 176.

${ }^{77}$ I. Kopernicki: s. 219.
} 
na powiece pojawiał się jęczmień - sięgali po maść zrobioną z zasuszonych mrówek zmieszanych z maścią bobkową ${ }^{78}$.

Ludwik Jucewicz zaobserwował, iż mieszkańcy wsi litewskiej „...od febry, leczą się gorzałką zmieszaną z sokiem mrówczanym"79. Zimnica, czyli malaria, nazywana również ograszką, trzęsionką, zimnem, trascą czy febrą, w XIX stuleciu wszechwładnie panowała na dawnych ziemiach polskich (nie tylko na terenach podmokłych, jak się przypuszcza), a najczęściej w jej terapii stosowano napoje wyskokowe z dodatkiem ziół i przeróżnych środków odzwierzęcych, od żmii poczynając ${ }^{80}$. W rejonie Kozienic (położonych na północy Małopolski) lecząc febrę, sięgano po mrówki. W celu przygotowania remedium należało

...przynieść mrówek z lasu, ugotować je w nowym garnku pod przykryciem, rozpalić kamień «z granicy» na czerwono, lać na niego wodę z mrówkami, nakryć się nad kamieniem i parzyć sięer.

„Suchoty prawdziwe” (gruźlicę) na Litwie próbowano leczyć również za pomocą mrówek. Wandalin Szukiewicz przytoczył receptę swojego dziadka, Macieja Karaczewskiego Wołłka:

Jaje świeże kurze, w urynie od tego który na suchoty choruie o północy wziętey, w garnuszku dobrze zaszpuntowanym twardo ugotować, a potym go szpikulcem z drzewa brzozowego zrobionym pokłóć i w gniazdo mrówczane włożyć, uznasz skutek $^{82}$.

Jak się wydaje, chorym oprócz mrówek mogła przynieść poprawę spora porcja magii, tak jaskrawo widoczna w tym remedium. Podobnie jak na Litwie postępowano na Ukrainie, z tym, że jajko gotowano dokładnie o północy.

O innym jeszcze środku stosowanym w leczeniu gruźlicy pisał Julian Talko-Hryncewicz.

W maju na mrowiskach w borach sosnowych o wschodzie słońca ma się formować masa wielkości kurzego jaja, biała i miękka, podobna do zbitego masła i niknąca po ociepleniu powietrza. Masę tę trzeba zebrać w szklane naczynie, mocno zakorkować, aby się nie ulotniła i trzymać w zimnem miejscu dając pić choremu po łyżce stołowej w mleku gorącym i wcierając ją w piersi i w plecy $^{83}$.

${ }^{78}$ J. Torliński: s. 132.

${ }^{79}$ L. Jucewicz: s. 335.

${ }^{80}$ L. Wdowiak: Zioła $w$ zwalczaniu ograżki, zwanej też trzęsionka czyli febry na dawnych ziemiach polskich na przełomie wieków XIX i XX [w:] Leki roślinne w terapii od czasów starożytnych po współczesne. Zagadnienia teoretyczne i praktyczne, red. B. Płonka-Syroka, A. Syroka, K. Sudoł, Wrocław 2013, s. 167-182.

${ }^{81}$ A. Wiśniewski: s. 642.

${ }^{82}$ W. Szuki ewicz: Dawne środki lecznicze, „Kwartalnik Litewski” t. 5: 1911 s. 128.

${ }^{83} \mathrm{~J}$. Talko-Hryncewicz: s. 159. 
Niektóre powody używania mrówek w lecznictwie ludowym mogły wzbudzić wesołość: „...dla pędzenia wiatrów jedzą mrówki” - napisał Aleksander Petrow (1847-1915) o mieszkańcach ziemi dobrzyńskieje ${ }^{84}$.

\section{Pszczoły miodne i trzmiele}

Oprócz mrówek, do najpopularniejszych owadów zaliczających się do rzędu błonkoskrzydłych i szeroko stosowanych w lecznictwie ludowym, należała rodzina pszczołowatych (Apidae), z której najważniejszą przedstawicielką była pszczoła miodna (Apis mellifera). Pszczoły, „boże robaki”85 darzono ogromnym szacunkiem („Pszczoła nie zdycha, tylko umiera”" ${ }^{86}$ ), a kradzież roju w oczach mieszkańców wioski uchodziła za jedno z największych przestępstw. Utrata pszczół stanowiła dla chłopów ogromny cios, toteż czyniono wszystko, by je ochraniać. „Miodu od pszczół nie trzeba dawać choremu, bo gdyby umarł, poginęłyby pszczoły" ${ }^{\prime 87}$ - przestrzegano na Podkarpaciu. „Miodu pszczelego nikt nie sprzeda na lekarstwo obawiając się, że gdyby chory umarł, cały rój spadnie, t. j. wniwecz się obróci, wyginie"88 - pisał o małopolskich wierzeniach Franciszek Gawełek.

Nie sposób omawiając pszczoły, nie wspomnieć o roli miodu i wosku, jednakże produkty te, używane w polskim lecznictwie ludowym dość powszechnie, nie doczekały się jeszcze osobnego szerokiego opracowania, pomimo imponującej liczby popularno-naukowych publikacji na temat wspaniałych zalet substancji pszczelich i ogromu informacji źródłowych traktujących o wykorzystywaniu miodu na wsi w dobie zaborów. Źródła nie wskazują na to, by ludność wiejska sięgała po pyłek pszczeli (pierzgę), kit i mleczko pszczele. Zadawalano się miodem, woskiem i jadem pszczelim, czasem używając „stoin” - suszu z pszczół ${ }^{89}$. Modne tak dzisiaj miodolecznictwo ${ }^{90}$, od dawna w lecznictwie ludowym zajmowało jedno z poczesnych miejsc, aczkolwiek nie zawsze stosowano miód w sposób przez nas oczekiwany i trudno było przewidzieć, w jakich dolegliwościach i w jaki sposób mógł on zostać użyty. Za przykład mogą posłużyć działania terapeutyczne podolskich znachorów, opisane przez Stanisława Spittala.

\footnotetext{
${ }^{84}$ A. Petrow: s. 139.

${ }^{85}$ W. Siar ko w ski : Materyjały do etnografii ludu polskiego z okolic Kielc, część druga , „Zbiór Wiadomości do Antropologii Krajowej" t. 3: 1879 cz. 3 s. 24.

${ }^{86}$ A. Petrow: s. 130.

${ }^{87}$ B. Gustawicz: O ludzie Podduklańskim w ogólności, a Iwoniczanach w szczególności, „Lud” t. 6: 1900 s. 62.

${ }^{88}$ F. Gawełek: s. 76.

${ }^{89}$ S. Jastrzębowski: s. 745.

${ }^{90}$ S. Stangaciu, E. Hartenstein: Leki z pszczelej apteki. Miodolecznictwo dla każdego, tłum. B. Floriańczyk, Warszawa 2007, s. 16.
} 


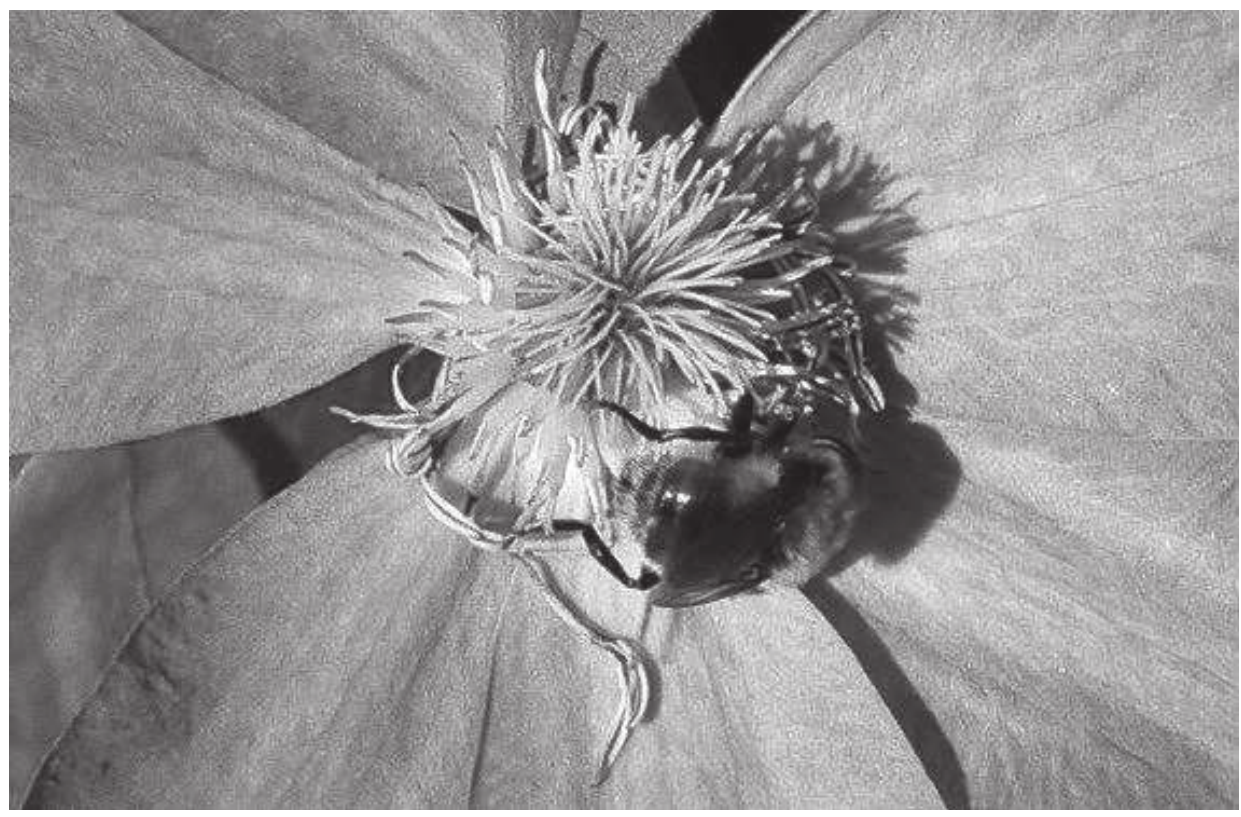

Il. 2. Trzmiel ziemny (Bombus terrestris) - fot. L. Wdowiak

Na pomieszanie rozumu jako pierwszy środek leczniczy używany jest miód pszczeli. Leją go choremu na głowę, a gdy wejdzie w głowę, chory wyzdrowieje, jeżeli nie, to na nic leczenie się zdało, bo chory już zawsze wariatem zostanie" ${ }^{\prime 1}$.

Wypada jednak w tym miejscu odnotować, że używano miodu skutecznie w walce z bardzo różnymi przypadłościami - poczynając od leczenia ukąszeń zadanych przez owady takie jak: pszczoły, osy czy szerszenie ${ }^{92}$, a na wzmacnianiu położnic kończą ${ }^{93}$. Miód pszczeli traktowano wręcz jako panaceum ${ }^{94}$.

Do jednej z podrodzin pszczołowatych należą trzmiele (Bombini). Ich miód według ludowych przekonań posiadał specjalne właściwości, lepsze jeszcze od miodu pszczelego, np. w leczeniu chorób oczu. Na Podkarpaciu miodu trzmielowego używano na „bolące oczne powieki, smarując je nim”, lecz także miał likwidować wypryski wokół ust. Miód trzmieli wkraplano w oczy również na Podolu „w zapaleniu spojówek, obrzękach i znacznym zaczerwienieniu”96. W Małopolsce miał spędzać

${ }^{91}$ S. Spittal: s. 155 .

92 Tamże, s. 217.

${ }^{93}$ A. Pleszczyński: s. 136.

${ }^{94} \mathrm{~L}$. Wd owiak: Miód jako uniwersalne lekarstwo ludności wiejskiej na dawnych ziemiach polskich w XIX i XX stuleciu, [w:] Historia panaceum. Między marzeniem a oszustwem, red. W. Korpalska, W. Ślusarczyk, Bydgoszcz 2016, s. 99-120.

${ }^{95}$ L. Magierowski: Leki używane przez lud polski we wsi Wesołej w pow. Brzozowskim, „Lud” t. 2: 1895 s. 156.

${ }^{96}$ S. Spittal: s. 216. 
z oczu „łuszczkę" ${ }^{\prime 97}$ (zaćmę). Na Białorusi uważano, iż podczas krupu należało „... smarować gardziel oraz szyję od przodu miodem trzmieli ziemnych"98.

Nieznana prawie dzisiaj w Polsce jaglica, bywała w przeszłości częstym powodem ślepoty. W leczeniu jaglicy na Podolu chłopi uciekali się do pomocy pszczół:

...doskonale ma leczyć jaglicę jad pszczeli. Schwytaną i trzymaną za skrzydełka pszczołę umieszczają na powiece i naciskają ją. Podrażniona w ten sposób pszczoła puszcza żądło w powiekę i wywołuje jej silny obrzęk. Gdy spuchlina minie, powtarzają zabieg jeszcze ze trzy do czterech razów. Kuracja taka ma być zupełnie skuteczna ${ }^{99}$ - pisał Stanisław Spittal.

Lecz przede wszystkim pszczeli jad uważany był w wielu regionach dawnych ziem polskich za niezwykle skuteczny środek w leczeniu gośćca stawowego. „Jad pszczoły, pochodzący z ukłucia żądłem, ma pomagać cierpiącym na reumatyzm"100 - mniemano w Małopolsce. Podobnie uważano na Podolu ${ }^{101}$. „Wystawiają cierpiące miejsce na ukąszenia pszczół"102 - donosił z Litwy Wandalin Szukiewicz. W okolicach Witebska pszczoły znalazły zastosowanie u pokąsanych przez żmije.

Na miejscu ukąszenia posadzić trzy żywe pszczoły, aby ukąsiły chorego, poczem rozetrzeć je na tym samym miejscu i zabandażować. Jednocześnie podają choremu do wewnątrz również trzy żywe pszczoły w chlebie zagniecione ${ }^{103}$.

Chyba najrzadziej stosowanym lekarstwem pochodzącym od pszczół, były wspomniane wcześniej suszone owady. W okolicach Opatowa dzieci słabowite, wychudzone (tzw. „suchotnicze”) kąpano w wodzie z dodatkiem suszu z pszczół (stoin) ${ }^{104}$. Na Ukrainie uznano suszone pszczoły za znakomity środek moczopędny, który usuwał wodną puchlinę. Chorym podawano „odwar pszona wygotowany z pszczołami”, bądź wysuszone pszczoły z wodą, używając 6 lub 9 owadów ${ }^{105}$. Rośliny zwane pszonem lub pszonakiem (Erysimum sp. - Brassicaceae) zawierały glikozydy nasercowe.

\section{Osy}

Z innych owadów błonkoskrzydłych, oprócz mrówek i pszczół, używano w lecznictwie os, które tworzą osobną rodzinę osowatych (Vespidae). Z osowatych największą obawę budzi szerszeń europejski (Vespa crabro), ale ukąszenie osy pospoli-

\footnotetext{
${ }^{97}$ F. Gawełek: s. 77; J. Świętek: Lud nadrabski... s. 617.

${ }^{98}$ F. Wereńko: s. 136.

${ }^{99}$ S. Spittal: s . 222-223.

${ }^{100}$ F. Gawełek: s. 76.

${ }^{101}$ S. Spittal: s. 222.

${ }^{102}$ W. Szukiewicz, Wierzenia... s. 440-441.

${ }^{103}$ F. Wereńko: s. 202.

${ }^{104}$ S. Jastrzębowski: s. 745.

${ }^{105} \mathrm{~J}$. Talko-Hryncewicz: s. 29, 444.
} 
tej (Vespula vulgaris) również nie należy do przyjemnych odczuć, chociaż natężenie bólu jest znacznie mniejsze niż w przypadku ugryzienia szerszenia. Odnaleziono dwie informacje (pochodzące z Białorusi) o używaniu osiego gniazda (aswapuzyr). Odwar z osiego gniazda podawano w kokluszu ${ }^{106}$, jak również okładano osim gniazdem miejsca poparzone, co podobno czyniono dość powszechnie ${ }^{107}$. Nic nie wskazuje na to, by używano samych owadów.

\section{Karaczany}

Kolejny rząd owadów - karaczany (Blattodea), czyli hełmce obejmuje insekty pospolicie zwane karaluchami; w dzisiejszej Polsce występuje ich 16 gatunków. W lecznictwie ludowym na terenie Białorusi używano karaczana wschodniego (Blatta orientalis) oraz prusaka (Blattella germanica). Powszechnie sporządzano z nich remedium zwalczające puchlinę wodną. W celu odwodnienia organizmu należało zażywać przez cztery dni po pięć sztuk „tarakanów”108. Sproszkowany karaczan wschodni służył w tym rejonie również jako środek przeciwko zimnicy ${ }^{109}$. Zygmunt Gloger (1845-1910) napisał, iż nad Narwią panowało przekonanie, iż „niektórzy ludzie umieją wyprowadzać z domu owady zwane tu prusakami lub francuzami i przeciwnie, nasyłać je przez zemstę"110.

\section{Świerszcze i pasikoniki}

Do innego już rzędu - Orthoptera należą świerszcze. W leczeniu wodnej puchliny sięgano na Białorusi po świerszcze domowe (Acheta domesticus) z rodziny świerszczowatych, które nazywano cwyrkunami. Na Ukrainie - ćwirkunami. Codziennie zalecano spożywać po kilka sztuk sproszkowanych świerszczy - „...działać mają jeszcze lepiej od tarakanów"111 - podawał Franciszek Wereńko. Także na Kujawach obrzęki leczono podając chorym rozgniecione w moździerzu świerszcze zalane spirytusem $^{112}$. Na Ukrainie w leczeniu wodnej puchliny również posługiwano się świerszczami. Przygotowywano z nich wywar. Podawano go choremu w tajemnicy, więc nie wiedział, co pije i nie brzydził się ćwirkunów ${ }^{113}$. Owad nie wszędzie był mile widziany. „Gdy świerszczek długo przemieszkuje, tam będzie ktoś chorował”

\footnotetext{
${ }^{106}$ F. Wereńko: s. 148.

${ }^{107}$ Tamże: s. 198.

108 Tamże: s. 165.

${ }^{109}$ Tamże: s. 168.

${ }^{110}$ Z. Gloge r : Zabobony i mniemania ludu nadnarwiańskiego tyczące ptaków, płazów i owadów, „Zbiór Wiadomości do Antropologii Krajowej” t. 1: 1877 cz. 3 s. 106.

${ }^{111}$ F. Wereńko: s. 165.

112 [An on im]: Notatka w rubryce Lecznictwo ludowe, „Wisła” t. 9: 1895 z. 2 s. 407.

${ }^{113}$ J. Talko-Hryncewicz: s. 187.
} 
- wierzono na Podkarpaciu ${ }^{114}$. Jednak na całym wschodzie dawnych ziem polskich mniemano, iż obecność świerszcza w obejściu pociąga za sobą szczęście. Należało jednak bardzo uważać, by go przypadkiem nie zabić, bowiem jego współziomkowie mścili się i za karę niszczyły w domu odzież. Na Ukrainie obawiano się dźwięków, jakie wydawały ćwirkuny, gdyż nie była to dobra wróżba ${ }^{115}$.

Do tego samego rzędu, co świerszcze - prostoskrzydłych (Orthoptera) należy pasikonik zielony (Tettigonia viridissima) z rodziny pasikonikowatych (Tettigoniidae). W okolicach Witebska często wykorzystywano tego owadziego drapieżcę zwanego kaziołem do odgryzania brodawek. Pasikonika zbliżano do brodawki, a owad „...broniąc się, odgryzał brodawkę"116. W Galicji dzieci „...schwyciwszy konika polnego, mówią do niego: koniku! koniku! dej mi maści na moje boleści!117 - pisał nauczyciel, Władysław Kosiński (1844-1914) . Bronisław Gustawicz przytoczył jeszcze inne wersje nakłaniania koników do współpracy - np.: „Koniku, koniku daj mi maści, to cię puszczę bez napaści”118 „Konikiem polnym” nazywano różne gatunki należące do pasikonikowatych, zarówno pasikonika śpiewającego, jak i miecznika łąkowego, czy łatczyna brodawnika. W chwili schwytania pasikoniki wydzielały „ostrą i piekącą ciecz”"119 (hemolimfę), którą uważano za substancję leczącą skaleczenia, czy owrzodzenia.

\section{Turkuć podjadek}

Do rzędu prostoskrzydłych zaliczono jeszcze innego insekta stosowanego w lecznictwie ludowym - kiedyś bardzo powszechnego turkucia podjadka (Gryllotalpa gryllotalpa) z rodziny turkuciowatych (Gryllotalpidae). Ten jeden z największych w Polsce owadów (osiąga ponad $6 \mathrm{~cm}$ ) prawie całe życie spędza pod ziemią, chociaż dysponuje długimi skrzydłami ${ }^{120}$. „Kruczek”, „niedźwiadek”, „podbij”"121, jak nazywano turkucia, nie jest zbyt lubiany przez ogrodników i rolników, ze względu na zniszczenia jakich dokonuje w korzeniach roślin. „Pić wódkę nalaną na żywego «turkucia»"- zalecano na Litwie jako remedium na zimnicę ${ }^{122}$.

Gdyby niedźwiadka powieszono na nitce w słoiku tak, aby powietrze nie miało przystępu, to utrzymują, iż natenczas się rozpłynie i służy za lekarstwo na wszystkie ukąszenia i rany

\footnotetext{
${ }^{114}$ B. Gustawicz: Podania... s. 166.

${ }^{115} \mathrm{~J}$. Talko-Hryncewicz: s. 187.

${ }^{116}$ F. Wereńko: s. 176.

${ }^{117}$ W. Ko siński: s. 30.

${ }^{118}$ B. Gustawicz: Podania... s. 137.

${ }^{119}$ M. Udziela: s. 219.

${ }^{120}$ H. Sandner: s. 230.

${ }^{121}$ B. Gustawicz: Podania... s. 168.

${ }^{122}$ W. Szuki ewicz: Wierzenia... s. 440.
} 
- pisał Bronisław Gustawicz o przekonaniach panujących na Pokuciu. W niektórych miejscowościach Małopolski wierzono, iż turkuć może być pomocny zarówno w zapobieganiu epilepsji u ludzi, jak i wzdęć u bydła:

Kto zobaczy niedźwiadka pierwszy raz w polu, powinien bić go palcem środkowym, aby nie chorował na wielką chorobę (Szczepanów, Zabełcze). Członkiem tego samego palca należy uderzyć w bok trzy razy bydlę, które wzdęcia dostało, a ma to być skuteczny środek do uleczenia chorego bydlęcia (Zabełcze) ${ }^{123}$.

Owad budził niepokój. „Niedźwiadek (turkuć) jak ugryzie cłeka - to cłek ginie” sądzono nieopodal Wieliczki ${ }^{124}$. Zygmunt Gloger podawał, że nad Narwią wierzono w to, że gdy turkuć odda mocz na skórę człowieka, będzie się ona jątrzyćc ${ }^{125}$. Zbliżone opinie panowały na zachodzie Galicji - nastąpienie stopą na turkucia miało powodować owrzodzenie stopy („podbij”) ${ }^{126}$.

\section{Pluskwiaki}

Zasiedlające szczeliny w ścianach wiejskich domów pluskwy (Cimex lectularius) należą do rzędu pluskwiaków różnoskrzydłych (Heteroptera), do rodziny pluskwowatych. Pluskwy, podobnie jak inne pasożyty ludzkie, budziły obrzydzenie. Na Podolu żółtaczkę leczono podając chorym „kurze jaje ugotowane na twardo i roztarte z pluskwą"127, natomiast w okolicach Witebska rozcierano kłapy (żywe, lub ususzone) z surowym jajkiem i tak przygotowaną miksturą leczono malarię ${ }^{128}$. W tym rejonie pluskwy utarte z cukrem miały być również „...cudownym środkiem przeciw suchotom”129. Stanisław Spittal podawał: „Rusini nacierają ciało chorego na padaczkę rozduszoną w palcach pluskwą" ${ }^{130}$. Wszystkie te działania miały na celu „zbrzydzić” chorobę - spowodować jej dyskomfort, nakłaniając do opuszczenia ciała ludzkiego. Błoszczycia, jak nazywano pluskwę na Ukrainie, również tam służyła do „zbrzydzania" chorób.

Do rzędu pluskwiaków równoskrzydłych (Homoptera) należą czerwce. Przylepione do korzeni niektórych roślin larwy czerwca polskiego (Porphynophora polonica) były zbierane przez chłopów w celu uzyskania karmazynowego barwnika ${ }^{131}$. Wiadomo również, iż używano go w lecznictwie w postaci roztworu wodnego

${ }^{123}$ B. Gustawicz: Podania... s. 168.

${ }^{124}$ S. Hradecka: Przyczynki do wierzeń ludu w Wierzbanowy, pow. Wieliczka, „Lud” t. 9: 1903 s. 65.

${ }^{125}$ Z. Gloger: s. 106.

${ }^{126}$ B. Gustawicz: Podania... s. 168.

${ }^{127}$ S. Spittal: s. 162.

${ }^{128}$ F. Wereńko: s. 168.

129 Tamże, s. 149.

${ }^{130}$ S. Spittal: s. 151.

${ }^{131}$ H. Sandner: s. 188. 
z octem i miodem. Podawano czerwiec w zranieniach, nieregularnej menstruacji, w trudnych porodach ${ }^{132}$, w myśl zasady similia similibus curantur. Używano również pluskwiaków w zbyt obfitych miesiączkach, lub gdy ciężarnej groziło poronienie $^{133}$. Preparaty z czerwca można było nabyć w aptekach. W etnograficznym materiale źródłowym nie naleziono potwierdzenia, by czerwce używane były w badanym okresie w lecznictwie ludowym. Dzisiaj czerwiec należy do owadów „skrajnie zagrożonych”134.

\section{Wszy}

Jeszcze częściej niż pluskiew, do „zbrzydzania” schorzeń używano wszy. Wesz ludzka (Pediculus humanus) przynależy do rzędu insektów Phthiraptera, do rodziny Pediculidae. „Zbrzydzanie” stosowano dość powszechnie w chorobach takich jak zimnica, czy żółtaczka (traktowana nie jako objaw choroby, lecz jako osobne schorzenie). Stanisław Spittal pisał, iż mieszkańcy Podola wierzyli, że

...środkiem, nigdy nie zawodzącym, jest zbrzydzenie żółtaczki. W tym celu podaje się choremu wszy do jedzenia, ale tak, by on sam o tym nie wiedział, bo wtedy z obrzydzenia nie mógłby powstrzymać się od wymiotów i wesz by nie skutkowała. Podają więc trzy razy dziennie po trzy wszy w chlebie, aby przez te cyfry kabalistyczne (3 i 9) wzmocnić jeszcze leczenie"135. Podobnie obrzydzano chorobie pobyt w ludzkim organizmie na Litwie: „na chleb kładą 9 wszy, zasmarowują to masłem i dają zjeść choremu, tak, aby nie wiedział, co je $\mathrm{e}^{136}$.

Ogromną liczbę żywych wszy należało spożywać w niektórych rejonach Ukrainy (trzy razy dziennie po 19 wszy), lub 9 wszy na czczo, dzieląc je na trzy chlebowe pigułki ${ }^{137}$. Barbara Szychowska-Boebel, która w końcu lat 60. i na początku lat 70. XX wieku prowadziła badania na Kujawach stwierdziła, że nadal stosowano tam „zbrzydzanie" żółtaczki za pomocą między innymi wszy ${ }^{138}$. Świadczy to o tym, jak silnie zakorzenione były przekonania o ich skuteczności.

${ }^{132}$ A. W. Jakubski: Czerwiec polski (Porphyrophora polonica (L.). Studium historyczne ze szczególnym uwzględnieniem roli czerwca w historii kultury, Warszawa 1934, s. 312-313.

${ }^{133}$ A. Trojan ow ska: Czerwiec, kermes i koszenila, czyli o owadach jako surowcach barwierskich i leczniczych w polskiej literaturze przyrodniczej do XIX w., „Analekta. Studia i Materiały z Dziejów Nauki" t. 17: 2008 nr 1-2 s. 19.

${ }^{134}$ B. Łagowska, K. Golan, K. Stepaniuk: Występowanie czerwca polskiego - Porphyrophora polonica (L.) (Hemiptera: Margarodidae) w Polsce oraz uwagi o jego cyklu życiowym, „Wiadomości Entomologiczne” t. 25: 2006 nr 1 s. 9.

${ }^{135}$ S. Spittal: s. 198.

${ }^{136}$ W. Szukiewicz: Wierzenia... s. 442.

${ }^{137} \mathrm{~J}$. Talko-Hryncewicz: s. 181.

${ }^{138}$ B. S zy ch ow ska-B o ebel: Lecznictwo ludowe na Kujawach. Materiały i rozważania, Toruń 1972, s. 40-41. 
Najczęstszymi środkami służącymi do zbrzydzenia febry są wszy. Wesz złapaną na koszuli chorego podają mu do zjedzenia w gałce chleba ${ }^{139}$ - zaobserwował na Podolu Stanisław Spittal.

Leczono zimnicę na północy Podlasia w podobny sposób. Silne wymioty „nieraz żółciowe” wywoływało jedzenie wszy w okolicach Tykocina ${ }^{140}$. 0 nieco zaskakującym wykorzystywaniu wszy w zatrzymaniu moczu na terenie Białorusi pisał Franciszek Wereńko: „...wesz świńską wpuszczają do kanału moczowego, podrażnienie przez nią sprawione usuwa zatrzymanie"141. W bardzo podobny sposób postępowano na Kaszubach, gdzie do cewki moczowej wprowadzano żywe „strechy” - stonogi ${ }^{142}$. Stonogi murowe (Oniscus asellus) stosowano bardzo często w lecznictwie ludowym, lecz chociaż kojarzą się z owadami, należą do skorupiaków.

\section{Muchy}

Do kolejnych owadów szeroko stosowanych w „zbrzydzaniu” choroby należały muchy, zwłaszcza mucha domowa (Musca domestica). Muchy zaliczono do rzędu muchówek. Wszędobylskie muchy we wszystkich zakątkach ziem polskich posądzano o roznoszenie chorób. „Nie trzeba zostawiać na drodze nieżywego raka, bo gdy mucha na nim usiądzie, a potym ukąsi człowieka, ten dostanie raka"143 - mniemano na Litwie. W Tarnowie również istniało tego typu przekonanie ${ }^{144}$. W okolicach Dobrzynia także wierzono, że mucha, która usiadła na zdechłym raku może zaszczepić raka osobie na której później usiadła ${ }^{145}$. Analogia pomiędzy nazwą skorupiaka i nazwą choroby spowodowała, iż w niektórych częściach dawnej Polski nie traktowano raków jako przysmaku. „Lud brzydzi się mięsem raka, nazywając je parszywym”"146 - napisał Franciszek Gawełek o mieszkańcach Małopolski.

Częściowo z powodu tych uprzedzeń, jak też wiedząc o tym, że owady dotykały również ekskrementów, muchy stosowano do „zbrzydzania” chorób najczęściej zimnicy. Bronisław Gustawicz pisał, iż na Podkarpaciu „trzy muchy z wodą wypić, dobrze jest na frybrę"147. Na Lubelszczyźnie wyławiano utopione muchy z pułapek, czy z mydlin i podawano chorym na trzęsionkę (zimnicę), aby

${ }^{139}$ S. Spittal: s. 162.

${ }^{140}$ J. Pełczyński: Dalszy ciąg przyczynków o lecznictwie ludowym w okolicach Tykocina gub. Łomżyńskiej, „Wisła. Miesięcznik Geograficzno-Etnograficzny” t. 6: 1892 z. 4 s. 911.

${ }^{141}$ F. Wereńko: s. 171.

${ }^{142}$ J. Torliński: s. 130.

${ }^{143}$ W. Szukiewicz: Wierzenia... s. 438.

${ }^{144}$ B. Gustawicz: Podania... s. 148.

${ }^{145}$ A. Petrow: s. 139.

${ }^{146}$ F. Gawełek: s. 76.

${ }^{147}$ B. Gu stawicz: O ludzie Podduklańskim... s. 61. 
sprowokować wymioty ${ }^{148}$. „Tak zwany jęczmień na oku leczą rozdartą muchą, kładąc ją w przeciwne ucho"149 - pisał Zygmunt Gloger o praktykach mieszkańców nadnarwiańskich wsi.

\section{Motyle}

Chyba najmniej używanym rzędem owadów, który wykorzystywano w lecznictwie ludowym były łuskoskrzydłe (Lepidoptera), czyli motyle. Niektóre z motyli budziły grozę - np. zmierzchnica trupia główka (Acherontia atropos) - ćma należąca do rodziny zawisakowatych, której pojawienie się w wielu miejscach Europy wróżyło śmierć ${ }^{150}$. Na Podolu nie łączono ropowicy (phlegmone), która pojawiała się na stopach, z nastąpieniem bosą nogą na turkucia podjadka. „Podbój, pidbij [...] zrobi się temu, kto bosą nogą stanie na gąsienicę zwaną podbojem (gąsienica prządki pierścienicy)"151 - pisał Stanisław Spittal. Dzisiaj prządkę pierścienicę (Malacosoma neustria), wyrządzającą duże szkody w sadach, nazywa się barczatką pierścieniówką bądź pierścienicą nadrzewną. „Groźną” liszkę tej ćmy w podłużne lazurowe, rdzawe,

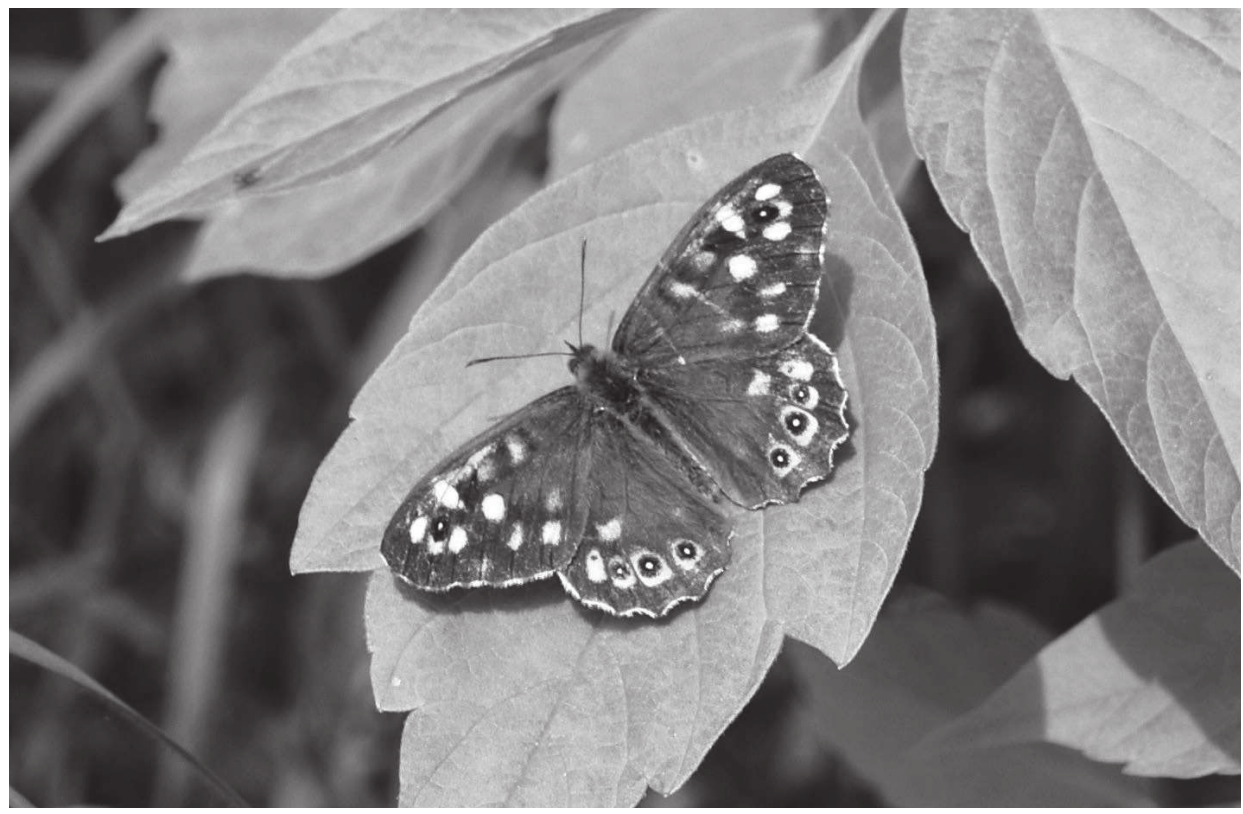

Il. 3. Osadnik egeria (Pararge aegeria) - fot. L. Wdowiak

${ }^{148}$ M. Dąb rowska: Leki ludowe, zebrane przez Stanisławę Dąbrowskq we wsi Żabnie, w pow. Krasnostawskim, „Wisła. Miesięcznik Geograficzno-Etnograficzny” t. 16: 1902 z. 3 s. 426.

149 Z. Gloger: s. 106.

150 J. Pone c: Motýle, Bratislava 1982, s. 154.

151 S. Spittal: s. 214. 
czarne pasy z białą linią biegnącą wzdłuż grzbietu skrzętnie omijano. Na Białorusi panowało przekonanie, iż krótkowzroczność (paniknica) może wystąpić na skutek dostania się do oczu pyłku motyli ${ }^{152}$. Na Wołyniu wierzono, iż „kto ćmę przypadkiem połknie, nienasyconym się staje"153. Odnaleziono tylko jedno doniesienie (ze Zbaraża) dotyczące stosowania pyłku motylego w leczeniu chorób dróg moczowych (jako środka moczopędnego). „Do pół szklanki wody wsypać uzbierany pyłek ze skrzydeł motyla kapustnika i wypić"154.

\section{Podsumowanie}

Chociaż w niniejszej pracy została prawie zupełnie pominięta problematyka ludowego miodolecznictwa okazało się, że po owady i ich produkty w leczeniu różnorakich schorzeń, ludność zamieszkała na dawnych ziemiach polskich w dobie zaborów i II Rzeczpospolitej sięgała dosyć często. Powszechnie korzystano w przypadku podejrzenia wścieklizny z chrząszczy z rodziny majkowatych, a w bólach stawów i paraliżu sięgano po pszczoły i mrówki. W zwalczaniu puchliny wodnej najbardziej rozpowszechnionymi remediami były również owady (należące do kilku rodzin). Muchami, wszami i pluskwami posługiwano się najczęściej do „zbrzydzania” choro-

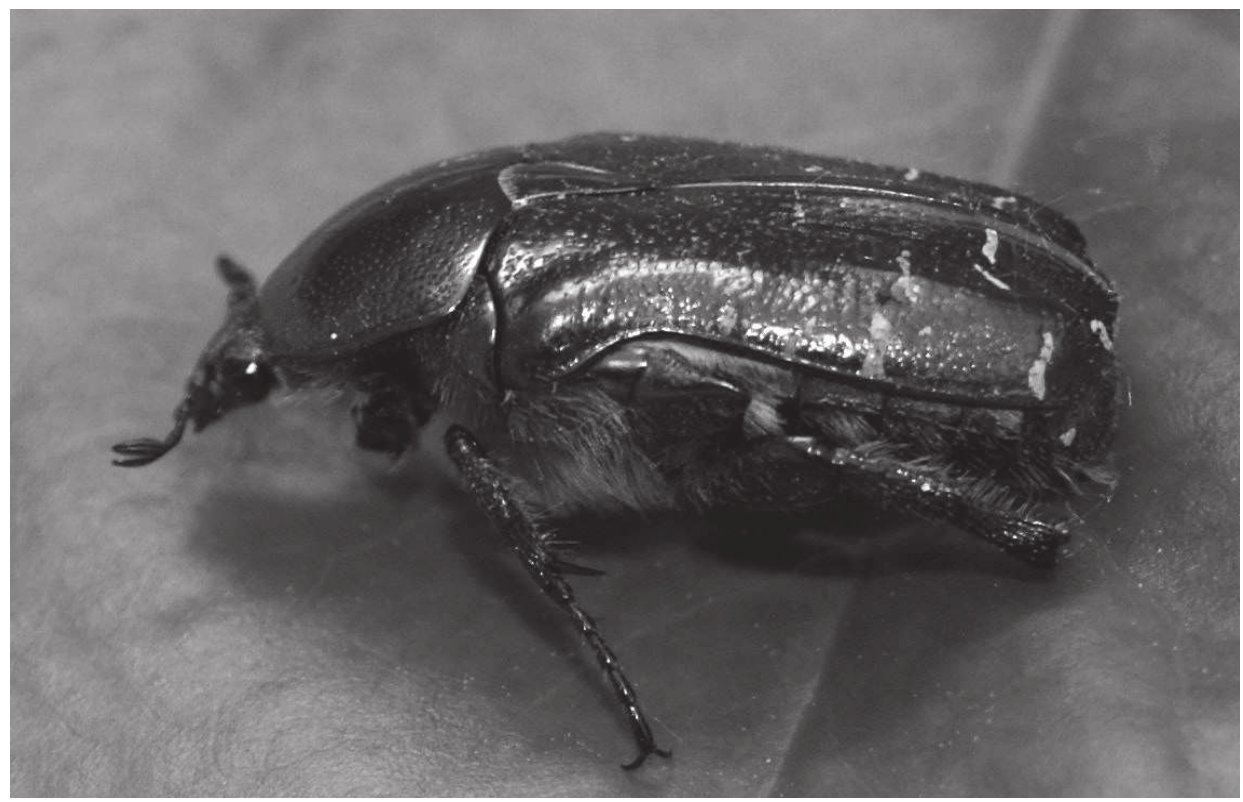

Il. 4. Kruszczyca złotawka (Cetonia aurata) - fot. L. Wdowiak

\footnotetext{
${ }^{152}$ F. Wereńko: s. 145.

${ }^{153}$ I. Kopernicki: s. 218.

${ }^{154}$ J. Talko-Hryncewicz: s. 183.
} 


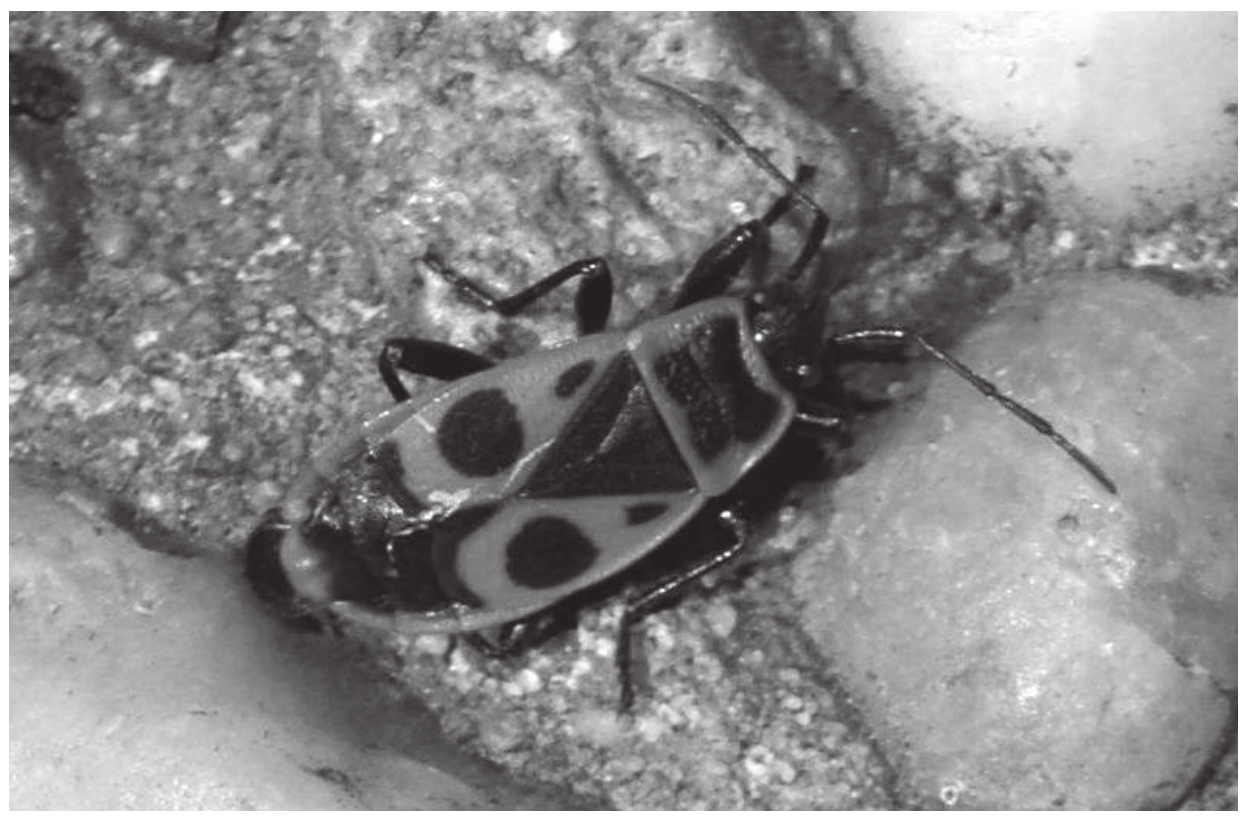

Il. 5. Kowal bezskrzydły (Pyrrhocoris apterus) - fot. L. Wdowiak

by. Zastanawia, że niektóre z powszechnie występujących insektów nie były w lecznictwie ludowym zupełnie wykorzystane - np. pchła, chociaż można przyjąć (za mieszkańcami Szczawnicy), iż sprzyjała gimnastyce: Gdy ludzie zniewieścieli i stali się tak powolnymi, że się zaledwie z miejsca ruszyć mogli, stworzył Bóg pchłę, aby człowieka do ruchu pobudzała"155. Nie wykorzystywano również dość powszechnie występujących, jednych z najpiękniejszych owadów żyjących w Polsce - kruszczycy złotawki, czy kowala bezskrzydłego. Jak można przypuszczać, kierowano się właściwościami owadów, a nie ich wyglądem.

Obawiano się wcześniej wspomnianych skorków, zwanych inaczej cęgoszami (Dermaptera), bowiem w mniemaniach ludowych wchodziły śpiącym w ucho i powodowały uszkodzenie słuchu. Nie lubiano ważek, bo miały „węzią” głowę i posądzano je o to, iż ich ugryzienie mogło zabić ${ }^{156}$. Istniało przekonanie, iż w ludzkich ranach żyje okazały, być może największy chrząszcz środkowoeuropejski - jelonek. Nie można go było się pozbyć, bo chory by umarł i trzeba go było dokarmiać mięsem, by nie toczył ciała ludzkiego ${ }^{157}$. Żydzi wierzyli, iż podeptanie wszy może sprowadzić „bladaczkę”, czyli anemię ${ }^{158}$. Lękano się turkucia podjadka, czy gąsienicy barczatki pierścieniówki, natomiast w materiale źródłowym nie napotkano informacji o strachu przed bolesnym, mogącym wywołać wstrząs ukąszeniem szerszenia, czy bąka

\footnotetext{
${ }^{155}$ B. Gustawicz: Podania... s. 153.

156 Tamże, s. 166.

${ }^{157}$ H. Bi eg el eis e n: Lecznictwo ludu polskiego, Kraków 1929, s. 92.

${ }^{158}$ B. W. S eg el: Wierzenia i lecznictwo ludowe Żydów, „Lud” t. 3: 1897 s. 55.
} 
lub ochroną bydła przed atakami krwiożerczych gzów. Obecności komarów zupełnie nie wiązano z zimnicą, co nie było niczym dziwnym w tych czasach, skoro sir Ronald Ross, angielski lekarz kolonialny dopiero w roku 1897 wykrył, iż widliszki przenoszą zarodźca malarii ${ }^{159}$.

Wielu owadów badacze kultury ludowej nie potrafili zidentyfikować. Na przykład w leczeniu hryżu (silne bóle w różnych okolicach ciała) na Białorusi używano „osikowych robaczków” ugotowanych w wodzie. „Robaczki owe mają być białe, drobne [...] i znajdują się wyłącznie na starych pniach osiki pod korą”160. „Zapewne jakieś gąsienice?" - zastanawiał się Franciszek Wereńko. Być może istotnie chodziło o gąsienice motyli - do lubiących żerować na topolach należała np. przeplatka maturna (Euphydryas maturna) ${ }^{161}$, z szaro-białymi gąsienicami, lecz pewności mieć nie można. Biało-kremowe larwy chrząszcza rzemlika topolowca (Saperda carcharias), jak nazwa wskazuje, również delektowały się topolowym drewnem ${ }^{162}$. Kłopoty z identyfikacją insektów napotykał również Oskar Kolberg, który napisał, że w leczeniu róży stosowano robaka, który usadowił się wewnątrz łodygi róży polnej „cierpiącą część twarzy się [nim] naciera”"163. „Wygnite ciało między palcami u nóg goi się pod mączką drzewną, utoczoną przez robaki”"164 - podawał Jan Świętek. Można jedynie domniemywać, które „robaki” produkowały ową mączkę.

W lecznictwie ludowym wykorzystywano również spowodowane przez owady galasy (narośla na liściach). Galasy wytwarzały muchówki, mszyce, roztocza, lecz najczęściej wiązano je z błonkówkami galasówkami (Cynipidae). Galasy zawierały znaczne ilości garbników ${ }^{165}$. Na Podolu korzystano z galasów dębowych, aby zatrzymać rozwolnienie. Miażdżono narośla i zalewano je na noc wódką ${ }^{166}$.

Na uwagę zasługuje, iż przy posługiwaniu się owadami jako środkami leczniczymi bardzo ważną rolę odgrywała liczba trzy i jej wielokrotności. Zastanawiające jest użycie na Ukrainie liczby „19”. Ani przy remediach roślinnych, ani przy innych niż owady środkach odzwierzęcych nie przywiązywano aż takiej wagi do liczb magicznych, jak w terapii za pomocą owadów. Bardzo ważną rolę odgrywały również inne formy działań magicznych, powodując wzmocnienie efektu placebo.

Jak wynika z tych rozważań, z rzędu chrząszczy używano najczęściej w lecznictwie ludowym do sporządzania lekarstw rodzin takich, jak: majkowate, poświętni-

${ }^{159}$ K. W. Zi eliński: Słownik pochodzenia nazw i określeń medycznych. Antyczne i nowożytne dzieje chorób w ich nazwach ukryte, Bielsko-Biała 2004, s. 346.

${ }^{160}$ F. Wereńko: s. 192.

${ }^{161}$ J. Ponec: s. 340.

${ }^{162}$ H. Sandner: s. 76.

${ }^{163}$ O. Kolberg: Tarnów - Rzeszów. Materyały etnograficzne, opr. S. Udziela, „Materyały Antropologiczno-Archeologiczne i Etnograficzne" t. 11: 1910 cz. 3 s. 297.

${ }^{164}$ J. Świ ęt tek: Lud nadrabski... s. 624.

${ }^{165}$ H. Sandner: s. 98-101.

${ }^{166}$ S. Spittal: s. 192. 


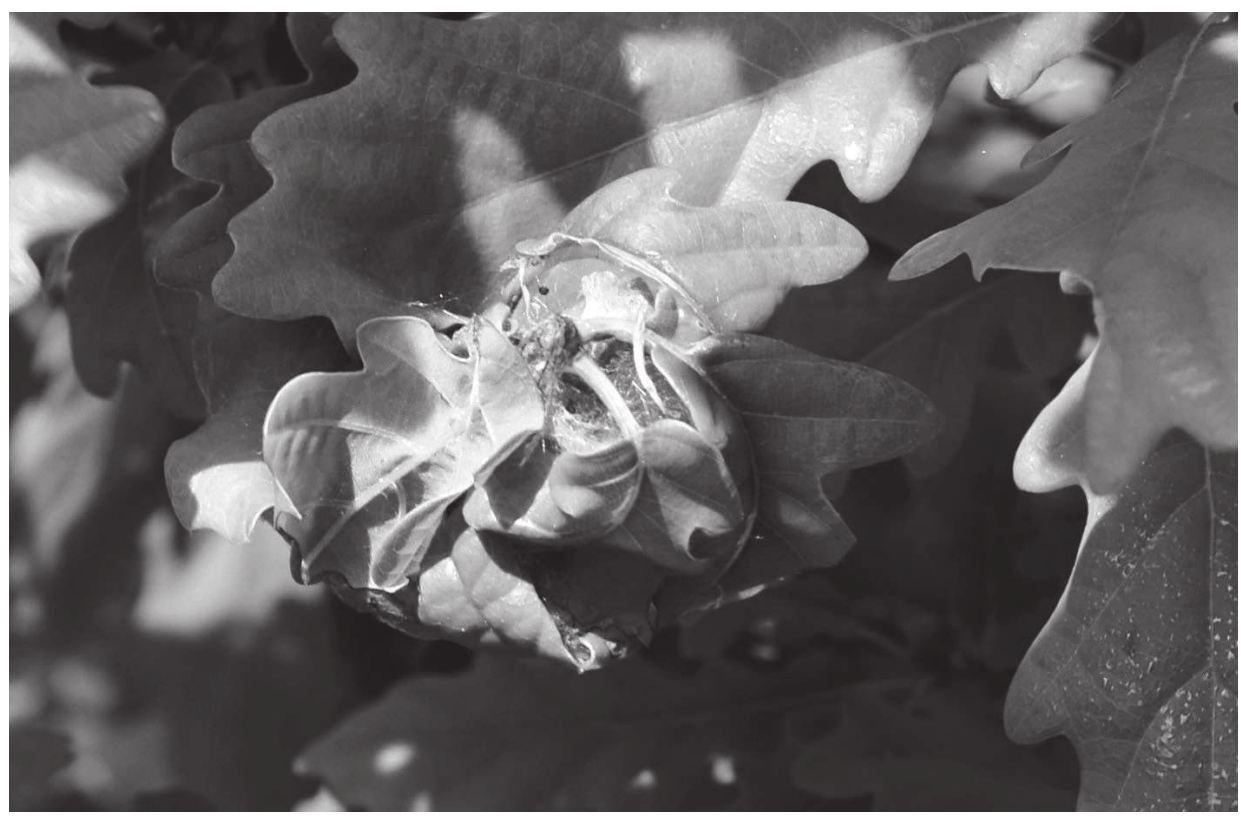

Il. 6. Budowa schronienia dla larw z liści dębu - fot. L. Wdowiak

kowate, świetlikowate oraz biedronkowate, rzadziej chrząszczy żerujących w drewnie i w pniach drzew. Z rzędu błonkoskrzydłych ogromną wagę przywiązywano do żądłówek: pszczołowatych, mrówkowatych i osowatych. Z muchówek stosowano zwykle rodzinę muchowatych. Z pluskwiaków różnoskrzydłych - pluskwowate. Rząd Phthiraptera reprezentowały wszowate. Z rzędu prostoskrzydłych używano świerszczowatych, pasikonikowatych i turkuciowatych. Z hełmców - karaczanowate i prusakowate. Łuskoskrzydłych (motyli) w lecznictwie ludowym używano rzadko, jednak trzeba wziąć pod uwagę, iż nie zawsze prawidłowo rozpoznawano ich gąsienice. Zwracano uwagę na dorosłe formy owadów, ale rzadko potrafiono określić ich larwy i poczwarki. Wyliczenie te pozwala przypuszczać, iż blisko 20 rodzin owadów znalazło zastosowanie w lecznictwie ludowym, natomiast wszystkich gatunków nie sposób jest wyliczyć, tym bardziej, że nie zawsze były one rozróżniane przez mieszkańców dawnych ziem polskich - zarówno chłopów, jak i badaczy ich kultury.

W porównaniu z lecznictwem ludowym, w akademickiej medycynie udział owadów należy uznać za skromny. W Pharmacopoeia Regni Poloniae (1817) zamieszczono opisy zaledwie dwudziestu surowców pochodzenia zwierzęcego. Z „owadzich” środków wymieniono: kantarydy, mrówki, miód, wosk żółty i wosk biały. Bardzo szczegółowo opisała je Anna Trojanowska ${ }^{167}$.

${ }^{167}$ A. Trojanowska: Farmakopealne leki pochodzenia zwierzęcego w polskiej literaturze naukowej 1800-1869, Warszawa 2012. 


\section{SPIS NAJWAŻNIEJSZYCH CYTOWANYCH PUBLIKACJI}

J. Bogdanowiczówna: Kilka notatek z medycyny ludowej, ze wsi Nadrybie w pow. Chełmskim, „Wisła. Miesięcznik Geograficzno-Etnograficzny” t. 10: 1896 z. 2 s. 345-348.

W. Czechowski, A. Radchenko, W. Czechowska, K. Vepsäläinen: The ants of Poland with reference to the myrmecofauna of Europe, Warszawa 2012.

M. Dąbrowska: Leki ludowe, zebrane przez Stanisławę Dąbrowskq we wsi Żabnie, w pow. Krasnostawskim, „Wisła. Miesięcznik Geograficzno-Etnograficzny” t. 16: 1902 z. 3 s. 425-429.

M. Federowski: Lud okolic Żarek, Siewierza i Pilicy. Jego zwyczaje, sposób życia, obrzędy, podania, gusła, zabobony, pieśni, zabawy, przysłowia, zagadki i właściwości mowy, t. 2, Warszawa 1889.

F. Gawełek: Przesq̨dy, zabobony, środki lecznicze i wiara ludu w Radłowie w pow. Brzeskim, „Materyały Antropologiczno - Archeologiczne i Etnograficzne” t. 11: 1910 cz. 3 s. 47-106.

Z. Gloger: Zabobony i mniemania ludu nadnarwiańskiego tyczące ptaków, płazów i owadów, „Zbiór Wiadomości do Antropologii Krajowej” t. 1: 1877 cz. 3 s. 101-107.

B. Gustawicz: O ludzie Podduklańskim w ogólności, a Iwoniczanach w szczególności, „Lud” t. 6: 1900 s. 36-80, 126-157, 245-257, 340-350.

B. Gustawicz: Podania, przesq̨dy, gadki i nazwy ludowe w dziedzinie przyrody. Część pierwsza. Zwierzęta, „Zbiór Wiadomości do Antropologii Krajowej” t. 5: 1881 cz. 3 s. 102-186.

S. Hrad ecka: Przyczynki do wierzeń ludu w Wierzbanowy, pow. Wieliczka, „Lud” t. 9: 1903 s. 64-68.

A.W. Jakubski: Czerwiec polski (Porphyrophora polonica (L.). Studium historyczne ze szczególnym uwzględnieniem roli czerwca w historii kultury, Warszawa 1934

S. Jastrzębowski: Mikułowice, pow. Opatowski, gub. Radomska. Sposoby leczenia suchot u małych dzieci, „Wisła. Miesięcznik Geograficzno-Etnograficzny” t. 7: 1893 s. 745-746.

E. Jeleńska: Wieś Komarowicze w powiecie mozyrskim. Dokończenie, „Wisła. Miesięcznik Geograficzno-Etnograficzny" t. 5: 1891 z. 2 s. 290-331, z. 3, s. 479-520.

L.A. Ju ce wicz: Litwa pod względem starożytnych zabytków, obyczajów i zwyczajów skreślona przez Ludwika z Poklewia, Wilno 1846.

J. Kantor: Czarny Dunajec, „Materyały Antropologiczno - Archeologiczne i Etnograficzne” t. 9: 1904 cz. 2 s. 21-229.

D.J. Karras, S.E. Farrell, R.A. Harrigan, F.M. Henretig, L. Gealt: Poisoning from „Spanish fly” (cantharidin), „The American Journal of Emergency Medicine” t. 14: $1996 \mathrm{nr} 5$ s. $478-483$.

O. Kolberg: Kujawy cz. 1, [w:] tenże: Dzieła wszystkie, t. 3, Warszawa 1962.

0. Kolberg: Tarnów - Rzeszów. Materyały etnograficzne, opr. S. Udziela, „Materyały Antropologiczno-Archeologiczne i Etnograficzne" t. 11: 1910 cz. 3 s. 116-323.

I. Kopernicki: Przyczynek do etnografii ludu ruskiego ma Wołyniu z materyjałów zebranych przez p. Zofiję Rokossowskq we wsi Jurkowszczyźnie w pow. Zwiahelskim, „Zbiór Wiadomości do Antropologii Krajowej" t. 11: 1887 cz. 3 s. 130-228.

W. Kosiński: Materyały etnograficzne zebrane w różnych okolicach Galicyi zachodniej, „Materyały Antropologiczno - Archeologiczne i Etnograficzne” t. 7: 1904 cz. 2 s. 1-86.

B. Łagowska, K. Golan, K. Stepaniuk: Występowanie czerwca polskiego - Porphyrophora polonica (L.) (Hemiptera: Margarodidae) w Polsce oraz uwagi o jego cyklu życiowym, „Wiadomości Entomologiczne" t. 25: 2006 nr 1 s. 5-14. 
L. Magierowski: Leki używane przez lud polski we wsi Wesołej w pow. Brzozowskim, „Lud” t. 2: 1895 s. $155-156$.

W. Marrené: Rzeczy ludowe włoskie, „Wisła. Miesięcznik Geograficzno-Etnograficzny” t. 3: 1889 z. 4 s. $793-844$.

T.T. Matecki: Apteczka domowa, Poznań 1860.

W.J. Meisner: Lekarstwo na wściekliznę (wodowstręt), „Piast czyli Pamiętnik Technologiczny. Obeymuiący przepisy dla gospodarstwa domowego i wieyskiego, ogrodnictwa, sztuk pięknych, rękodzielń i rzemiosł; niemniey lekarstwa domowe, pospolite i zwierzęce" t. 19: 1830 s. $121-143$.

A. Milewska: Medycyna ludowa, „Wisła. Miesięcznik Geograficzno-Etnograficzny” t. 5: 1891 z. 2 s. 419-424.

K. Nakwaska: Dwór wiejski. Dzieło poświęcone gospodyniom polskim. Przydatne i osobom w mieście mieszkającym, t. 3, Lipsk 1860.

M. Parczewska: Lecznictwo ludowe. Środki lecznicze używane u ludu w okolicach Kalisza, „Wisła. Miesięcznik Geograficzno-Etnograficzny” t. 10: 1896 z. 2 s. 342-344.

J. Pełczyński: Dalszy ciąg przyczynków o lecznictwie ludowym w okolicach Tykocina gub. Łomżyńskiej, „Wisła. Miesięcznik Geograficzno-Etnograficzny” t. 6: 1892 z. 4 s. 911- 916.

A. Petrow: Lud ziemi Dobrzyńskiej, jego charakter, mowa, zwyczaje, obrzędy, pieśni, przysłowia, zagadki it. p., „Zbiór Wiadomości do Antropologii Krajowej” t. 2: 1878 cz. 3 s. 3-182.

A. Pleszczyński: Bojarzy Międzyrzeccy. Studjum etnograficzne, Warszawa 1892.

Pobratymi ec [J.S. Płatkowski]: Środki lecznicze i ich nazwy aptekarskie u ludu (z powiatu myślenickiego), „Lud” t. 5: 1899 s. 164-166.

J. Ponec: Motýle, Bratislava 1982.

H. Sandner: Owady, Warszawa 1989.

H. Sarn owska: Niektóre sposoby leczenia na Kujawach, „Wisła. Miesięcznik Geograficzno-Etnograficzny" t. 10: 1896 z. 2 s. 345

J.J. Schneider: Maikäfersuppen, ein vortreffliches und kräftiges Nahrungsmittel, „Magazin für die Staatsarzneikunde" t. 3: 1844 nr 3 s. 403-405.

B.W. Segel: Wierzenia i lecznictwo ludowe Żydów, „Lud” t. 3: 1897 s. 49-61.

W. Siarkowski: Materyjały do etnografii ludu polskiego z okolic Kielc, część druga, „Zbiór Wiadomości do Antropologii Krajowej" t. 3: 1879 cz. 3 s. 3-61.

S. Spittal: Lecznictwo ludowe w Załoźcach i okolicy. Materiały dotyczqce sposobów leczenia, zielarstwa, wierzeń, zabobonów i znachorstwa, „Rocznik Podolski” t. 1: 1938 s. 62- 225.

St. Z. [Z. Staniszewska]: Znad Buga, „Lud” t. 3: 1897 s. 7-46.

S. Stangaciu, E. Hartenstein: Leki z pszczelej apteki. Miodolecznictwo dla każdego, tłum. B. Floriańczyk, Warszawa 2007.

W. Szuki ewicz: Dawne środki lecznicze, „Kwartalnik Litewski” t. 5: 1911 s. 125-128.

W. Szukiewicz: Wierzenia i praktyki ludowe (zabobony, przesądy, wróżba i t. d.), zebrane w gubernji Wileńskiej (Dokończenie), „Wisła” t.17: 1903 z. 3 s. 265-280, z. 4 s. 432-444.

B. Szychowska-Bo ebel: Lecznictwo ludowe na Kujawach. Materiały i rozważania, Toruń 1972.

J. Świętek: Liczby Trzy i Dziewięć w mitach, wyobrażeniach, mistycznych praktykach i w zwyczajach ludowych, „Lud” t. 11: 1905 s. 371-388.

J. Świętek: Lud nadrabski od Gdowa po Bochnię. Obraz etnograficzny, Kraków 1893. 
J. Talko-Hryncewicz: Zarysy lecznictwa ludowego na Rusi Południowej, Kraków 1893.

J. Torliński: Przesq̨dy i zwyczaje lecznicze kaszubskich rybaków nadmorskich, „Archiwum Historii i Filozofii Medycyny i Historii Nauk Przyrodniczych" t. 17: 1938 z. 1-2 s. 105-166.

A. Trojanowska: Czerwiec, kermes i koszenila, czyli o owadach jako surowcach barwierskich i leczniczych w polskiej literaturze przyrodniczej do XIX w., „Analekta. Studia i Materiały z Dziejów Nauki" t. 17: 2008 nr 1-2 s. 15-31.

M. Udziela: Medycyna i przesądy lecznicze ludu polskiego. Przyczynek do etnografii polskiej, Warszawa 1891.

S. Udziela: Materyjały etnograficzne z miasta Ropczyc i okolicy, Kraków 1886.

L. Wdowiak: Miód jako uniwersalne lekarstwo ludności wiejskiej na dawnych ziemiach polskich w XIX i XX stuleciu, [w:] Historia panaceum. Między marzeniem a oszustwem, red. W. Korpalska, W. Ślusarczyk, Bydgoszcz 2016, s. 99-120.

L. Wdowiak: Zioła $w$ zwalczaniu ograżki, zwanej też trzęsionka czyli febry na dawnych ziemiach polskich na przełomie wieków XIX i XX [w:] Leki roślinne w terapii od czasów starożytnych po współczesne. Zagadnienia teoretyczne i praktyczne, red. B. Płonka-Syroka, A. Syroka, K. Sudoł, Wrocław 2013, s. 167-182.

F. Wereńko: Przyczynek do lecznictwa ludowego, „Materyały Antropologiczno-Archeologiczne i Etnograficzne" t. 1: 1896 cz. 2 s. 99-228.

W. Wielogłowski: Medycyna wiejska. Obrazek z obyczajów ludu wiejskiego, Kraków 1863.

A. Wiśni ewski: Lecznictwo ludowe, „Wisła. Miesięcznik Geograficzno-Etnograficzny” t. 5: 1891 z. 3 s. 642-646.

O. Zadurska: „Każdy ma swego robaka”. O owadach w polskiej medycynie ludowej, „Tekstura. Rocznik Filologiczno-Kulturoznawczy" t. 1: 2013 s. 27-37.

K.W. Zieliński: Słownik pochodzenia nazw i określeń medycznych. Antyczne i nowożytne dzieje chorób w ich nazwach ukryte, Bielsko-Biała 2004. 